\title{
Targeted Nano-Drug Delivery of Colchicine against Colon Cancer Cells by Means of Mesoporous Silica Nanoparticles
}

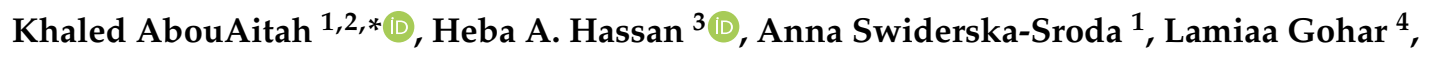 \\ Olfat G. Shaker ${ }^{5}{ }^{\oplus}$, Jacek Wojnarowicz ${ }^{1}{ }^{\oplus}$, Agnieszka Opalinska ${ }^{1}$, Julita Smalc-Koziorowska ${ }^{6}$, \\ Stanislaw Gierlotka ${ }^{1}$ and Witold Lojkowski ${ }^{1}$ (D) \\ 1 Laboratory of Nanostructures, Institute of High Pressure Physics, Polish Academy of Sciences, \\ Sokolowska 29/37, 01-142 Warsaw, Poland; a.swiderska-sroda@labnano.pl (A.S.-S.); \\ j.wojnarowicz@labnano.pl (J.W.); a.opalinska@labnano.pl (A.O.); xray@unipress.waw.pl (S.G.); \\ w.lojkowski@labnano.pl (W.L.) \\ 2 Medicinal and Aromatic Plants Research Department, Pharmaceutical and Drug Industries Research \\ Division, National Research Centre (NRC), Dokki, Giza 12622, Egypt \\ 3 Therapeutic Chemistry Department, Pharmaceutical and Drug Industries Research Division, \\ National Research Centre (NRC), Dokki, Giza 12622, Egypt; hassan_heba59@yahoo.com \\ 4 Pharmacognosy Department, Pharmaceutical and Drug Industries Research Division, \\ National Research Centre (NRC), Dokki, Giza 12622, Egypt; la_gohar@hotmail.com \\ 5 Medical Biochemistry and Molecular Biology Department, Faculty of Medicine, Cairo University, \\ Cairo 11511,Egypt; olfatshaker@yahoo.com \\ 6 Laboratory of Semiconductor Characterization, Institute of High Pressure Physics, Polish Academy of \\ Sciences, Sokolowska 29/37, 01-142 Warsaw, Poland; julita@unipress.waw.pl \\ * Correspondence: k.abouaitah@labnano.pl; Tel.: +48-22-888-0429
}

Received: 3 December 2019; Accepted: 3 January 2020; Published: 7 January 2020

\begin{abstract}
Antimitotics are important anticancer agents and include the natural alkaloid prodrug colchicine (COL). However, a major challenge of using COL as an anticancer drug is its cytotoxicity. We developed a novel drug delivery system (DDS) for COL using mesoporous silica nanoparticles (MSNs). The MSNs were functionalized with phosphonate groups, loaded with COL, and coated with folic acid chitosan-glycine complex. The resulting nanoformulation, called MSNsPCOL/CG-FA, was tested for action against cancer and normal cell lines. The anticancer effect was highly enhanced for MSNsPCOL/CG-FA compared to COL. In the case of HCT116 cells, 100\% inhibition was achieved. The efficiency of MSNsPCOL/CG-FA ranked in this order: HCT116 (colon cancer) > HepG2 (liver cancer) > PC3 (prostate cancer). MSNsPCOL/CG-FA exhibited low cytotoxicity (4\%) compared to COL $(\sim 60 \%)$ in BJ1 normal cells. The mechanism of action was studied in detail for HCT116 cells and found to be primarily intrinsic apoptosis caused by an enhanced antimitotic effect. Furthermore, a contribution of genetic regulation (metastasis-associated lung adenocarcinoma transcript 1 (MALAT 1), and microRNA (mir-205)) and immunotherapy effects (angiopoietin-2 (Ang-2 protein) and programmed cell death protein 1 (PD-1) was found. Therefore, this study shows enhanced anticancer effects and reduced cytotoxicity of COL with targeted delivery compared to free COL and is a novel method of developing cancer immunotherapy using a low-cost small-molecule natural prodrug.
\end{abstract}

Keywords: colchicine alkaloid; colon cancer cells; mesoporous silica nanoparticles; targeted delivery system; apoptosis; PD-1 immune checkpoint inhibitor and cancer immunotherapy 


\section{Introduction}

Colchicine (COL) is a natural alkaloid compound derived mainly from the medicinal plant Colchicum automnale and has been used in the clinic for treating gout and familial Mediterranean fever. COL has also shown some benefit in primary biliary cirrhosis [1], amyloidosis [2], and condyloma acuminate treatments [3]. COL is an antimitotic drug, which interferes strongly with cell division by affecting microtubule assembly and disassembly during mitosis. Most of the antimitotic drugs are toxic anticancer agents, which preferentially kill cancer cells, as they divide much faster than normal cells. However, the major challenge for COL is its toxicity, which causes severe side effects to patients [4].

Despite COL not yet being used clinically for cancer therapy because of its toxicity to normal cells, it is used as a lead compound in generating potent anticancer agents [5-9]. To reduce the side effects of COL on normal cells, many types of research have included analogs of COL $[10,11]$ and combination treatments with other drugs [12]. Regarding the mechanism underlying the antimitotic effects of COL, several actions are associated with antimitotic and post-antimitotic responses. Gupta and Dudani [13] proposed that the mechanism of action for antimitotic drugs, such as COL, includes blockade of cell growth at metaphase upon the binding of antimitotic drugs to tubulin (for COL through the colchicine binding site) due to cell-cycle arrest (e.g., at G2/M). Following this action, the microtubules cannot exert any cellular functions [13]. In the presence of antimitotic drugs, cells either die during mitosis or exit mitosis. When they exit mitosis, several post-mitotic responses occur that can lead to cell death, including cell-cycle arrest and apoptosis [14]. In a report on the mitotic cell death that occurs during mitosis, Castedo et al. [15] proposed that the mitotic cell death catastrophe results from a combination of deficient cell-cycle checkpoints and cellular damage. Cell death occurring during mitosis is characterized by activation of caspase- 2 in response to DNA damage, or caspase- 9 , caspase- 3 , and cytochrome $\mathrm{c}$ in response to mitochondrial membrane permeabilization. These effectors make up the molecular hallmarks of apoptosis. Thus, mitotic catastrophe is controlled by molecular players, including cell cycle-specific kinases, cell-cycle checkpoint proteins, caspases, and some proteins of the Bcl-2 family (e.g., Bax, Bcl-2), among others. Qi et al. provided evidence that, by arresting cell cycle progression in the presence of antimitotic drugs, mitotic spindles are disrupted, and cancer cells directly undergo apoptosis via the mitotic catastrophe [16].

Recently, antimitotic agents such as COL were reported to have a regulatory effect on most immune cell types, leading to the development of effective cancer immunotherapies [17]. With respect to cancer immunotherapy, targeting programmed cell death protein 1 (PD-1) and programmed cell death-ligand 1 (PD-L1), among other immune checkpoints, is important. PD-1 is an inducible immune modulatory receptor expressed on surface-activated T cells, and its ligand PD-L1 is expressed on cancer cells [18]. Binding PD-1 to PD-L1 leads to prevent from the immune antitumor effects by T cells against cancer cells [19]. However, recent studies have revealed the intrinsic expression of PD-1 in many cancers, along with immune $\mathrm{T}$ cells $[20,21]$. Therefore, it is considered a new potential target for cancer immunotherapy $[19,21]$. Thus, checkpoint blockade immunotherapy has revolutionized treatment for many tumors. In the next few years, scientists will be able to focus on immunotherapy research and broaden target cancers with different strategies [22]. Recently, the regulatory action by which antimitotic drugs inhibit PD-1 over-expression on the surface of T-cells was highlighted, and that PD-1 is strongly inhibited in the presence of the COL-binding site (CBS) of tubulin [23].

Traditional treatments for cancer, including surgery, radiation, cryosurgery, and chemotherapy, can be used alone or in combination. These methods have several limitations, such as toxicity, side effects, and expense. When chemotherapy is considered, normal treatment protocols include anticancer drugs alone or in combination to inhibit/kill cancer cells by affecting cell division and proliferation through different mechanisms. Drugs can produce various side effects for patients (e.g., neutropenia, liver and gastrointestinal toxicity, anemia, mucositis, and others) [24]. Therefore, cancer-targeting delivery systems with different nano-platforms have gained attention [25-27].

Despite the promising anticancer effects of COL, a few COL drug delivery systems (DDSs) have been tested to improve its therapeutic efficiency through cancer-targeting [28,29]. We focused 
on developing a novel DDS for COL by facilitating the active targeting of cancer cells. In the current study, we constructed a DDS for COL using three-dimensional fibrous dendritic mesoporous silica nanoparticles with a spherical shape (MSNs) known as KCC-1 type [26,30]. MSNs have been investigated as a drug delivery carrier for several drugs and biomolecules [27,31,32]. The tailored DDS comprises MSNs functionalized with phosphonate functional groups (MSNsP), and then loaded with COL MSNsPCOL, with the latter product subsequently coated with chitosan-glycine conjugated to folic acid (FA) to obtain a nanoformulation called MSNsPCOL/CG-FA. Glycine was employed as a source of amino groups that require for cancer growth [33]. FA was employed as the main targeting ligand, which is known for its binding potential to folate receptors, which are over-expressed on many cancers and facilitate the endocytosis pathway [26,34-36].

\section{Results and Discussion}

\subsection{Synthesis and Characterization of the Targeted Delivery System}

The targeted drug delivery system for COL, MSNsPCOL/CG-FA, comprised COL-loaded MSNsP subsequently coated with chitosan-glycine conjugated to folic acid. The schematic representation of the process is shown in Figure 1.

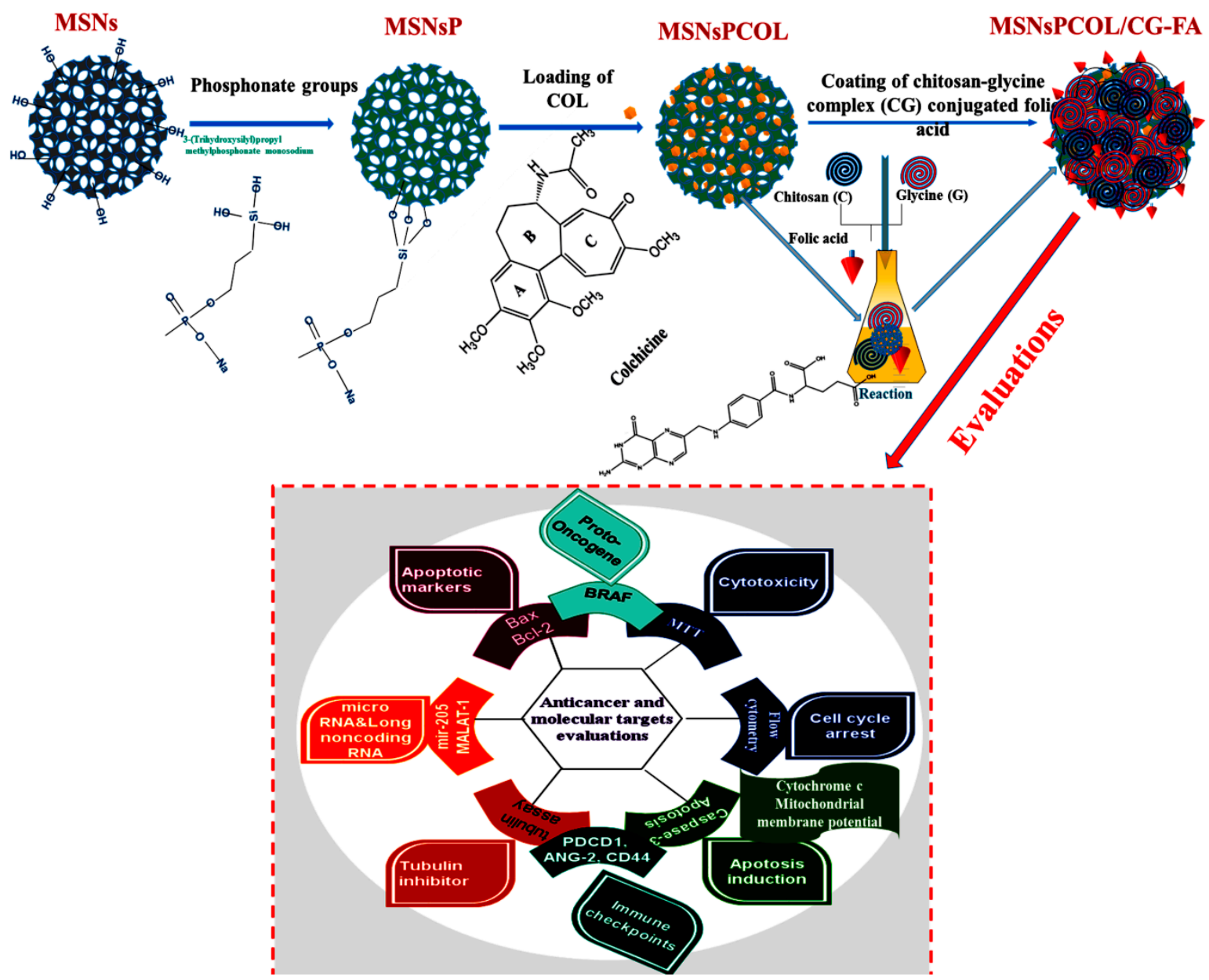

Figure 1. Schematic representation of the steps to obtain the proposed drug delivery system with the final product (MSNsPCOL/CG-FA) and various biological evaluations in vitro. 


\subsection{Electron Microscopy of Materials}

To observe the structural changes between the prepared materials, we used TEM STEM and FE-SEM techniques. The FE-SEM images (Figure 2A) show the 3D dendritic mesoporous structure of MSNs with a spherical shape that is uniform in size. No aggregation was seen. In TEM images (Figure 2B), there were no detectable differences between MSNs, MSNsP, and MSNsPCOL. However, in MSNsPCOL/CG-FA, the central part appeared gray-white in color due to the coating complex (chitosan-glycine). This observation is similar to that seen in STEM images, where MSNsPCOL/CG-FA was white in color (Figure 2C). Thus, the coating was confirmed by STEM and TEM observations.
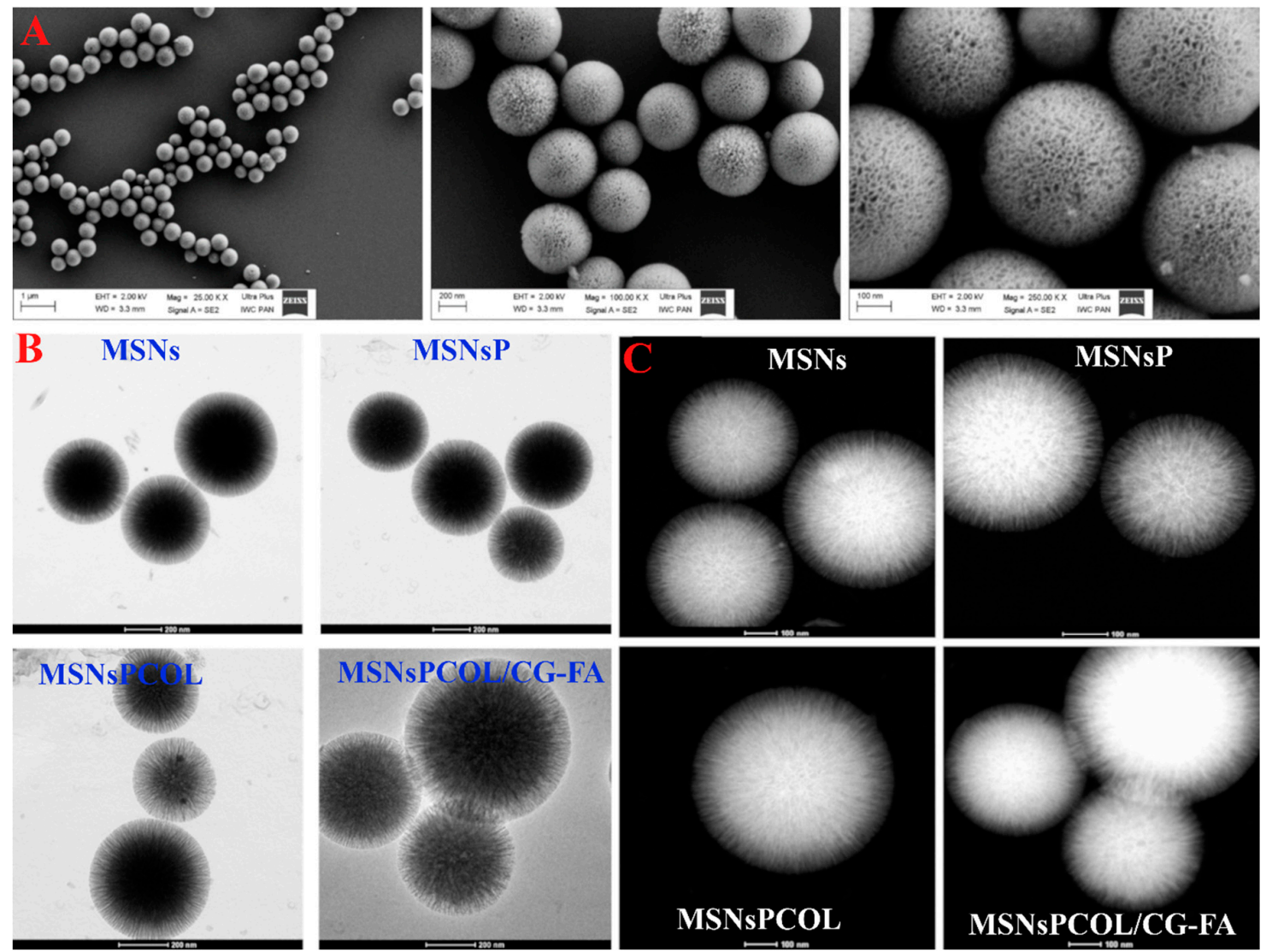

Figure 2. Morphological structures of the materials. (A) Field emission scanning electron microscopy (FE-SEM) of prepared mesoporous silica nanoparticles (MSNs) at different magnifications. (B) High-resolution transmission electron microscopy (HR-TEM) of prepared materials at different stages: Before and after of modification, colchicine (COL) loading, and coating. (C) Scanning transmission electron microscopy (STEM) of prepared materials at different stages: before and after of modification, COL loading, and coating.

\subsection{Surface Area Characteristics}

The specific surface area and pore volume characteristics were measured (Table 1). Via modification with phosphonates, COL loading, and coating with CG-FA, both surface area and total pore volume were decreased compared to MSNs $\left(380.1 \mathrm{~m}^{2} / \mathrm{g}\right.$ and $0.772 \mathrm{~cm}^{3} / \mathrm{g}$ of specific surface area and total pore volume, respectively). This observation indicates successful preparation, in agreement with previous results $[26,27,37,38]$. 
Table 1. Physicochemical properties of MSNs before and after colchicine loading and polymer coating.

\begin{tabular}{|c|c|c|c|}
\hline Sample Code & $\begin{array}{c}\mathrm{S}_{\mathrm{BET}} \\
\left(\mathrm{m}^{2} / \mathrm{g}\right)\end{array}$ & $\begin{array}{l}\text { Total Pore Volume a } \\
\left(\mathrm{cm}^{3} / \mathrm{g}\right)\end{array}$ & $\begin{array}{l}\text { P, COL, CG-FA Content Calculation from } \\
\text { Weight Loss }\left(w t^{2}\right)^{b}\end{array}$ \\
\hline MSNs & 380.1 & 0.772 & 3.3 \\
\hline MSNsP & 202.1 & 0.489 & 6.98 as $\mathrm{P}$ \\
\hline MSNsPCOL & 181.8 & 0.467 & 3.60 as COL \\
\hline MSNsPCOL/CG-FA & 89.5 & 0.352 & 33.48 as CG-FA \\
\hline
\end{tabular}

\subsection{Elemental Content Analysis}

Energy-dispersive X-ray spectroscopy allowed us to determine the changes in the elemental content of prepared materials (Figure S1A, Supporting Information). Prior to modification, MSNs were composed of $53.18 \mathrm{wt} \% \mathrm{Si}$ and $46.82 \mathrm{wt} \% \mathrm{O}$. Additional modification with organic phosphonate groups changed the elemental content, resulting in the presence of new elements, including $0.24 \mathrm{wt} \% \mathrm{P}$, $7.40 \mathrm{wt} \% \mathrm{C}$, and $0.95 \mathrm{wt} \% \mathrm{Na}$, as seen for MSNsP, confirming the modification. With further loading of COL on MSNsP, the C content increased and P content decreased in MSNsPCOL as a result of COL loading because it is an organic compound. Further polymer coating of MSNsPCOL relatively increased the $\mathrm{C}$ amount to $9.92 \mathrm{wt} \%$ and $\mathrm{N}$ amount to $2.77 \mathrm{wt} \%$ in MSNsPCOL/CG-FA. This observation is expected because both chitosan and glycine are composed of amino groups, which is important for confirmation of the coating process.

\subsection{Particle Size Measurement}

The particle size distribution was measured by nanoparticle tracking analysis (NTA) in aqueous solution (Figure S1B, Supporting Information). The mean size distribution for MSNs was $324 \pm 33.2 \mathrm{~nm}$. For MSNsP, the size increased to $407 \pm 13.9 \mathrm{~nm}$. For MSNsPCOL, the size slightly decreased to $391 \pm 3.9 \mathrm{~nm}$ but was an insignificant difference. Unexpectedly, MSNsPCOL/CG-FA size decreased to $330 \pm 22.2 \mathrm{~nm}$ compared to MSNsPCOL. An explanation may be the coating used for most of the particles with a smaller size compared to particles with a larger size, leading to an increase in their average size in the sample. This observation is in agreement with the two peaks appearing at $10-200 \mathrm{~nm}$, which has not been observed previously.

\subsection{Functional Group Determination}

FTIR was used to identify surface functional groups (Figure 3). MSNs had several peaks at 450,800 , and $1056 \mathrm{~cm}^{-1}$ because of the siliceous mesostructured framework. As their surface was functionalized with phosphonate groups in MSNsP, we observed a new band at $953 \mathrm{~cm}^{-1}$ and a broad peak from 3000 to $3600 \mathrm{~cm}^{-1}$, reflecting phosphonate groups [39]. Two new peaks at $1639 \mathrm{~cm}^{-1}$, and an intensive peak centered at $3355 \mathrm{~cm}^{-1}$ were presented in MSNsPCOL, corresponding to shifted peaks at 1542 and $3629 \mathrm{~cm}^{-1}$ for COL. Additional coating resulted in several new peaks, with bands at 698 and $946 \mathrm{~cm}^{-1}$ attributed to chitosan, glycine, or folic acid. A band at $1315 \mathrm{~cm}^{-1}$ could correspond to chitosan, a band at $1436 \mathrm{~cm}^{-1}$ could correspond to either chitosan or folic acid, but a band at $2900 \mathrm{~cm}^{-1}$ could correspond to folic acid. A peak centered at $1034 \mathrm{~cm}^{-1}$ became broader, which ascribes all components for coating. 

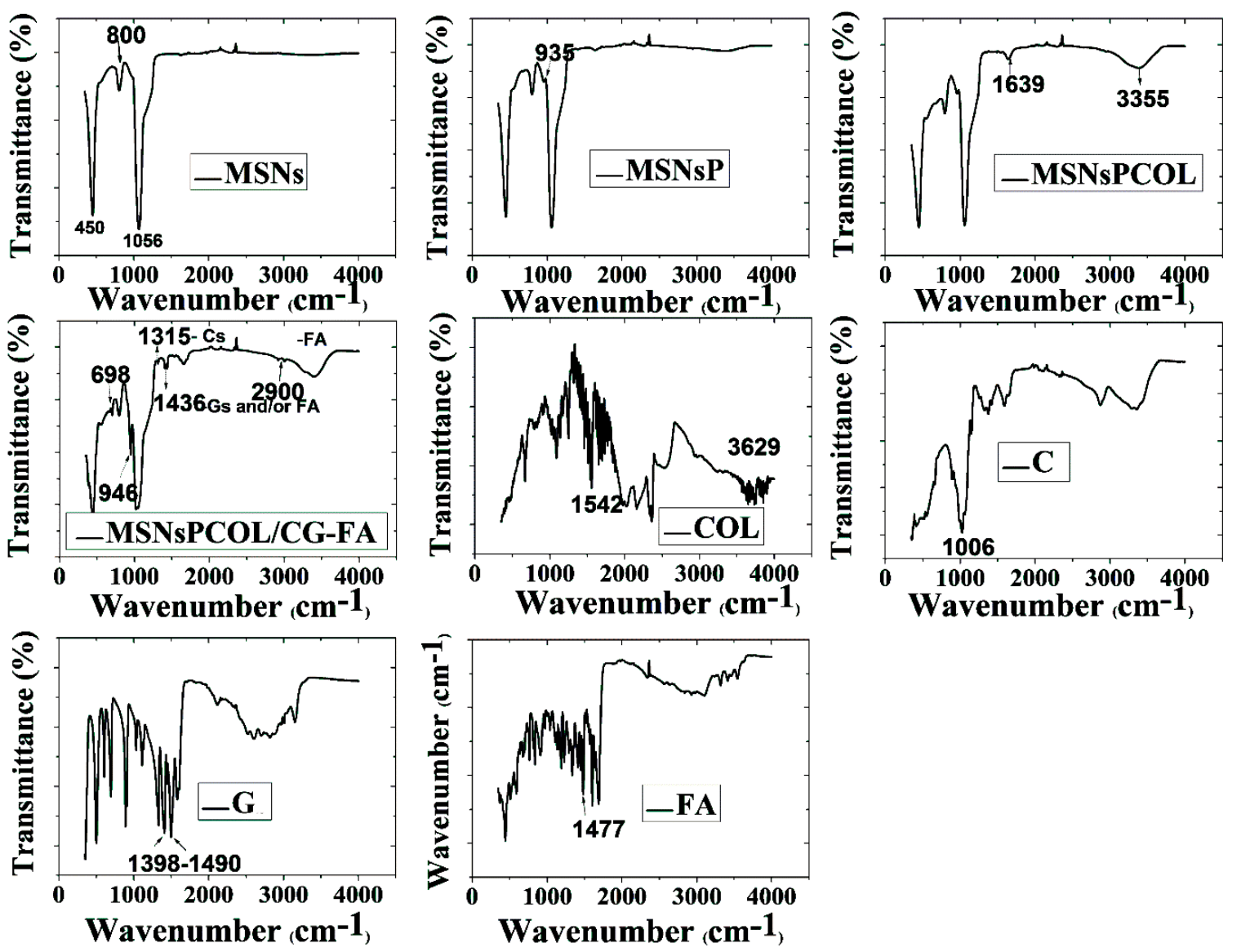

Figure 3. Fourier transform infrared spectroscopy (FTIR) spectra of MSNs before and after modification and COL loading, as well as chitosan (C), and glycine (G), folic acid (FA), and COL.

\subsection{Simultaneous Thermal Analysis (STA-DSC) and XRD Characterization}

To identify the mass fraction of phosphonate groups, $\mathrm{COL}$, and polymer, thermal analysis was performed by calculating the weight loss values over their thermal decomposition (Figure 4A and Table 1). MSNs lost $\sim 3.32 \mathrm{wt} \%$ because of moisture content. The weight loss further increased with MSNsP resulting from the decomposition of phosphonate groups. The heating of MSNsPCOL resulted in increased loss compared to MSNsP, which was calculated as COL loaded on MSNsP (3.60 $\mathrm{wt} \%$ ). The highest weight loss was recorded for MSNsPCOL/CG-FA, which was the result of decomposition of the coating complex (calculated to be $33.4 \mathrm{wt} \%$ ), which confirms successful fabrication of the coating.

The results of the DTG thermograms in Figure $4 \mathrm{~B}$ are consistent with STA, providing clear data that confirm the degradation. In MSNsP, a peak at $63^{\circ} \mathrm{C}$ showed moisture, and another at $500{ }^{\circ} \mathrm{C}$ was attributed to organic decomposition. The degradation of COL was confirmed with the peak in the range of 340 to $525{ }^{\circ} \mathrm{C}$ in MSNsPCOL based on the two maximum peaks at $342{ }^{\circ} \mathrm{C}$ and $550{ }^{\circ} \mathrm{C}$ for free COL. A peak recorded at $106^{\circ} \mathrm{C}$ in MSNsPCOL/CG-FA corresponded to decomposition of the coating material.

To further understand whether COL loaded on the surface of or inside particles, differential scanning calorimetry (DSC) analysis was conducted. Figure $4 \mathrm{C}$ shows no peaks in the MSNsPCOL and MSNsPCOL/CG-FA spectrum corresponding to free COL melting $\left(409\right.$ to $\left.537^{\circ} \mathrm{C}\right)$. This observation shows that COL was enclosed in the particles.

To further verify the DSC results, we used XRD analysis. Figure 4D illustrates that no peaks appeared in the MSNsPCOL pattern corresponding to COL. We propose two reasons for this finding: Low loading and entrapment in pores. To confirm that we created a physical mixture of MSNsP and COL, no peaks were observed corresponding to COL. The MSNsPCOL/CG-FA pattern did 
not represent any peaks corresponding to chitosan, glycine, or folic acid, confirming the DSC data. These two complementary techniques show the characteristics of the meso-porosity of MSNs allowing the accommodation of various molecules, including functional groups, polymers, and drugs.
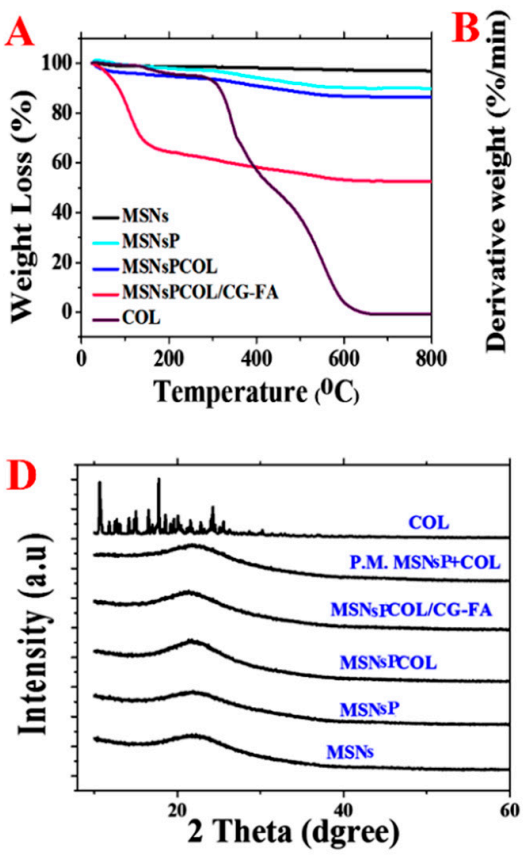
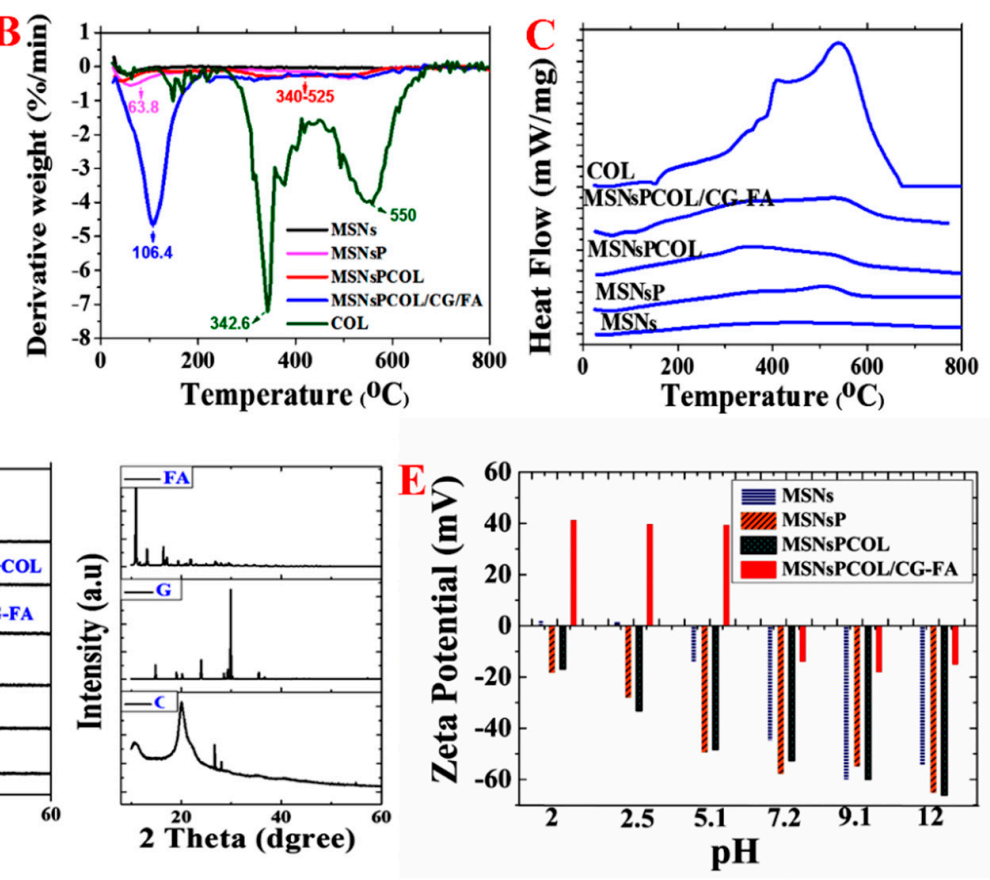

Figure 4. Thermal analysis of materials. (A) Simultaneous thermal analysis (STA) before and after surface modification, COL loading, and coating. (B) DTG analysis before and after surface modification, COL loading, and coating. (C) Differential scanning calorimetry (DSC) analysis before and after surface modification, COL loading, and coating. (D) X-ray diffraction (XRD) analysis before and after surface modification, COL loading, and coating. (E) Zeta potential measurements in aqueous solution before and after surface modification, COL loading, and coating.

\subsection{Zeta Potential Measurements}

Figure 4E shows the differences in zeta potential for the materials and $\mathrm{pH}$ conditions. MSNs had a very low positive value $(<+2 \mathrm{mV})$ in acidic media and very negative in alkaline medium $(-55 \mathrm{mV})$. As expected, MSNsP had negative zeta values compared to MSNs associated with phosphonate groups. MSNsPCOL exhibited negative values at various $\mathrm{pH}$ values, probably due to the low COL content in particles. MSNsPCOL/CG-FA exhibited high positive values $(>+40 \mathrm{mV})$ when medium was acidic ( $\mathrm{pH}$ 2, 2.5 and 5.1). This observation is important for the cellular uptake of these particles by cancer cells to reach tumor sites. Negative values were found for MSNsPCOL/CG-FA particles in neutral or alkaline medium ( $\mathrm{pH} 7.2,9.9$ and 12). The high positive zeta values for MSNsPCOL/CG-FA particles suggest that they can enter cells via endocytosis. The surface charge of particles (neutral, anionic, and cationic charges) determines their internalization into cells. Anionic nanoparticles are less efficiently internalized than cationic and neutral particles [40-43]. These results suggest that the developed DDS leads to higher cellular uptake in cancer cells.

\subsection{MSN Cytotoxicity Evaluation}

Figure 5 presents the dependence of cell inhibition on concentration, time, cell line, and MSNs, with significant differences at $p<0.5$. A gradual cell inhibition effect was found only when cells were treated with either MSNs or MSNsP at an increased concentration of $1000 \mu \mathrm{g} / \mathrm{mL}$ and incubation for $72 \mathrm{~h}$. Higher cytotoxicity was recorded for HCT116 cells than PC3 and HepG2 cells, with $1000 \mu \mathrm{g} / \mathrm{mL}$ MSN and MSNsP treatment of HCT116 cells resulting in $85.9 \pm 6.0 \%$ and $77.4 \pm 4.7 \%$ inhibition, respectively. In contrast, normal BJ1 cells were less inhibited than cancer cells under the same treatment conditions. 

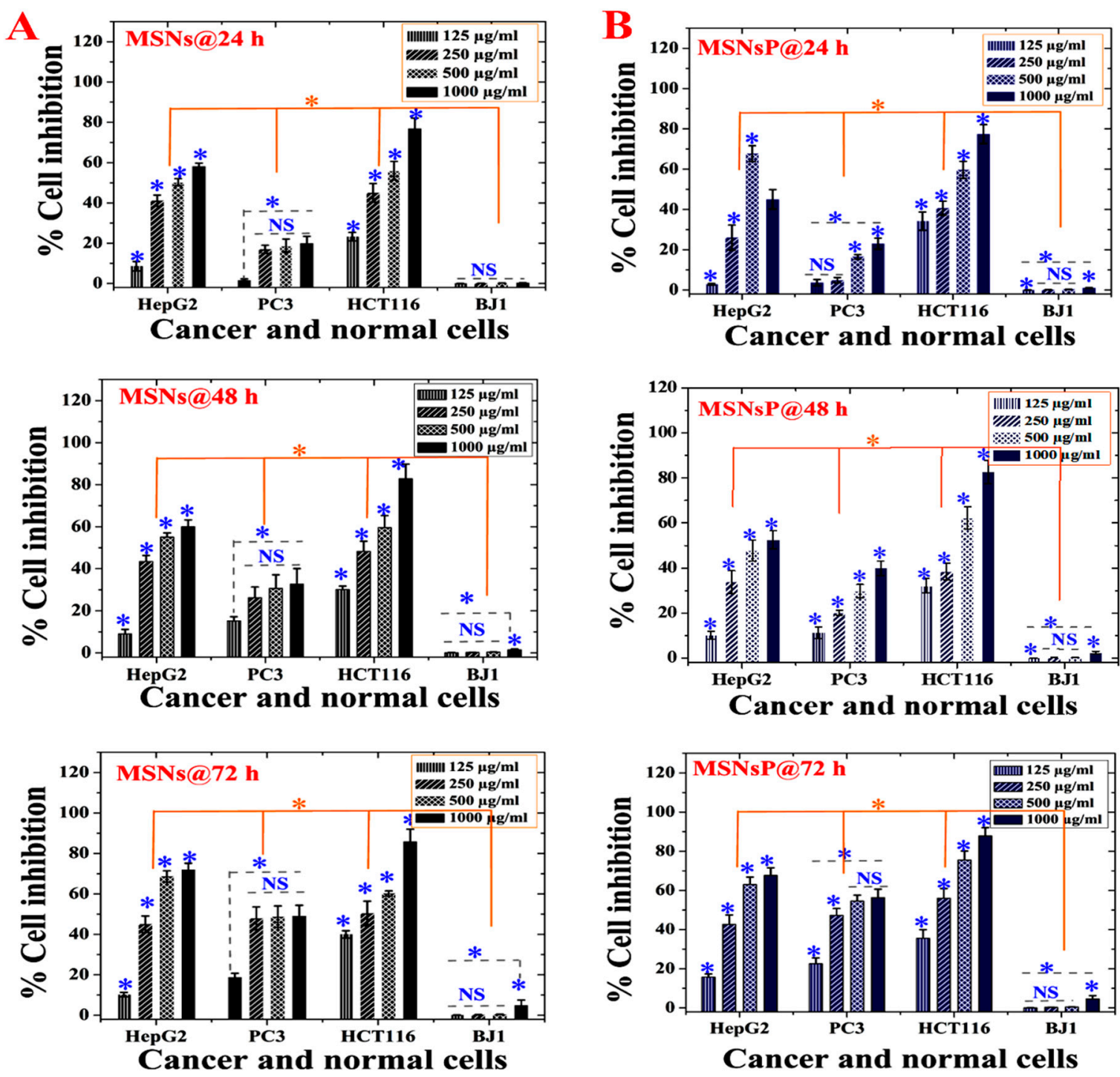

Figure 5. In vitro cytotoxicity (as percent inhibition) of MSNs and MSNs functionalized with phosphonate functional groups (MSNsP) for biocompatibility evaluations in cancer and normal cell lines after 24, 48, and $72 \mathrm{~h}$ of incubation with cancer cells (liver, HepG2; prostate, PC3; and colon, HCT116) and normal fibroblasts (BJ1). (A) Cytotoxicity of MSNs towards cell lines. (B) Cytotoxicity of MSNsP towards cell lines. Note: A blue asterisk $\left(^{*}\right)$ indicates significant $(p<0.05)$ differences between tested concentrations, whereas an orange asterisk $\left(^{*}\right)$ indicates significant differences between cell lines. NS, not significant. All data are expressed as mean \pm SD.

The toxicity differences between MSNs and MSNsP varied according to cell line in response to concentration and time (Table S1 in Supplementary Information). With the IC50 value, it is possible to identify the differences in cytotoxicity; MSNs had a more toxic effect on HepG2 and HCT116 cells after $48 \mathrm{~h}$ compared to other incubations. In contrast, MSNsP had a more toxic effect on HCT116 cells after 24 and $72 \mathrm{~h}$ compared to $48 \mathrm{~h}$. In addition, HCT116 cells were more sensitive than other cancer cell lines. Both types of nanoparticles had nearly equal IC50 values in PC3 cells after 24 and $48 \mathrm{~h}$. Negligible cytotoxicity (IC50 > $1000 \mu \mathrm{g} / \mathrm{mL}$ ) was observed for normal BJ1 cells in response to both types of nanoparticles. The negligible cytotoxicity on BJ1 normal cells can be related to the low internalization of nanoparticles in BJ1 normal cells. There is evidence in literature that cancer cells allow higher nanoparticles internalization compared normal cells due to the enhanced permeation and retention effect [44]. This, because of the vasculature of tumors, is often leaky, leading to accumulating nanoparticles in the bloodstream compared to normal tissue [45]. This finding agrees with previously 
published data for MCF-7 cells and BJ cells treated with MSNs and phosphonate-functionalized MSNs [39]. They mentioned that cancer cells uptake more MSNs than normal cells, and MSNs are more cytotoxic for cancer cells compared normal cells. Therefore, either MSNs or MSNsP is a promising nanocarrier for COL delivery.

\subsection{In Vitro Anticancer Effects against Cancer Cells}

We studied the anticancer activity in terms of cell inhibition and found that it was significantly dependent on the cell line, concentration, incubation time, and delivery method. For HepG2 cells (Figure 6A), high inhibition was observed after $72 \mathrm{~h}$ and $200 \mu \mathrm{g} / \mathrm{mL}$ of all treatments. Regarding the role of the delivery route, MSNsPCOL/CG-FA exhibited high inhibition (80-82\%), especially at 100 and $200 \mu \mathrm{g} / \mathrm{mL}$, compared to MSNsPCOL and COL. This finding was also confirmed by IC50 values, with lower values detected for three incubation times with MSNsPCOL/CG-FA (Table S1 in Supplementary Information). Obviously, these results indicate that the anticancer activity against HepG2 cells was ranked in the following order: MSNsPCOL/CG-FA > COL > MSNsPCOL/CG-FA.

As shown in Figure 6B, PC3 cells were significantly inhibited by increasing dose and incubation time. Notably, MSNsPCOL/CG-FA had a gradual inhibitory effect compared to carriers; it had lower inhibition at $24 \mathrm{~h}$ and increased after $72 \mathrm{~h}$, with a maximum inhibition of $80 \%$ when treated at $200 \mu \mathrm{g} / \mathrm{mL}$. The anticancer effect in PC3 cells was ranked in this order: MSNsPCOL/CG-FA > COL > MSNsPCOL. This effect was also confirmed by IC50 values (Table S1 in Supplementary Information), with lower values obtained for MSNsPCOL/CG-FA compared to other treatments.

Interestingly, HCT116 cancer cells were highly inhibited compared to HepG2 and PC3 (Figure 6C). We observed that at a high concentration of $200 \mu \mathrm{g} / \mathrm{mL}$ MSNsPCOL, MSNsPCOL/CG-FA, and COL inhibited $100 \%$ at 24,48 , and $72 \mathrm{~h}$. However, differences were seen among the three treatments when the concentration was decreased. MSNsPCOL/CG-FA potentially inhibited HCT116 growth $>90 \%$ after $72 \mathrm{~h}$ compared to other carriers. Clear differences were confirmed by IC50 calculations, as MSNsPCOL/CG-FA had lower values than MSNsPCOL and COL and reached $19.7 \mu \mathrm{g} / \mathrm{mL}$ after $24 \mathrm{~h}, 17.4 \mu \mathrm{g} / \mathrm{mL}$ after $48 \mathrm{~h}$, and $17.0 \mu \mathrm{g} / \mathrm{mL}$ after $72 \mathrm{~h}$. The anticancer activity pattern against HCT116 was ranked in this order: MSNsPCOL/CG-FA $>$ COL $>$ MSNsPCOL. Thus, the findings concerning anticancer effects in three cancer cell lines show that HCT116 cells were more sensitive than HepG2 and PC 3 cancer cells. Therefore, we selected HCT116 cancer cells for further investigation in our study.

For normal BJ1 cells, we observed that the inhibitory effect depended on the concentration and delivery route (Figure $6 \mathrm{D}$ ). MSNsPCOL/CG-FA inhibited $4 \%$ after $72 \mathrm{~h}$, compared to $60 \%$ for $\mathrm{COL}$, which indicates negligible effects. As seen in the IC50 values (Table S1 in Supplementary Information), the delivery COL in the nano or free form had IC50 values $>100 \mu \mathrm{g} / \mathrm{mL}$. MSNsPCOL/CG-FA significantly inhibited all tested cancer cells lines than COL ranking in this order: HCT116 > HepG2 > PC3. Also, MSNsPCOL/CG-FA had less or negligible toxic effects on normal BJ1 cells versus cancer cells than COL. Thus, this effect is the most likely to be developed as a DDS for cancer therapy.

From the observations, the proposed delivery route has an enhanced anticancer effect with a longer duration to $72 \mathrm{~h}$. The reason for this is that the anticancer effect is in response to COL release from nanoformulations because it is controlled by a coating that needs some time for degradation. The polymeric coating controls the release of guest molecules from MSNs depending on time, $\mathrm{pH}$, and other factors $[27,31,46]$. The enhanced anticancer effects with MSNsPCOL/CG-FA compared to free COL supports a cancer-targeting effect. This is possible through the interaction of folate receptors in cells and folic acid in nanoparticles. The sensitivity of HCT116 cancer cells to MSNsPCOL/CG-FA compared to HepG2 and PC3 is because folate receptors are overexpressed among cancer cell types [36]. It was shown that expression levels of folate receptors vary depending on type of cancer and the colorectal cancers show higher level than liver and prostate cancers [47]. However, the anticancer effect of free COL or enhanced delivery route is in response to inherited antimitotic effects from COL. 

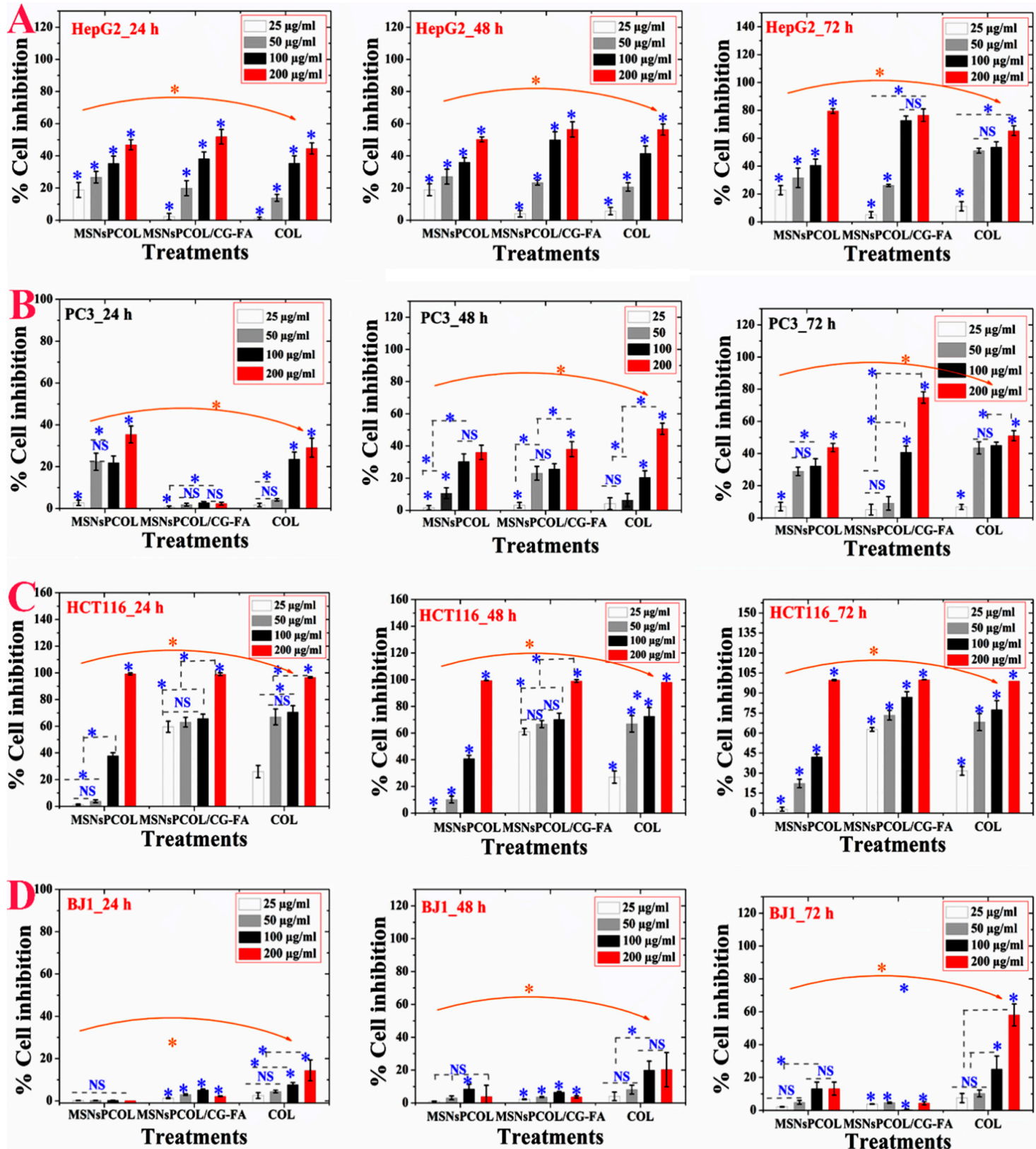

Figure 6. In vitro cytotoxicity (as percent inhibition) of the proposed delivery system in cancer and normal cells after 24, 48, and $72 \mathrm{~h}$ of incubation with cells. (A) Anticancer effects on HepG2 cancer cells. (B) Anticancer effects on PC3 cancer cells. (C) Anticancer effects on HCT116 cancer cells. (D) Anticancer effects on BJ1 normal cells. Note: A blue asterisk $\left(^{*}\right)$ indicates significant $(p<0.05)$ differences between tested concentrations, whereas an orange asterisk ${ }^{*}$ ) indicates significant differences between tested samples (nanoformulations and COL). NS, not significant. All data are expressed as mean \pm SD.

\subsection{Inhibition of Tubulin Activity in HCT116 Cancer Cells}

As shown in Figure 7A, MSNs and MSNsP significantly inhibited tubulin in response to increasing the concentration used to treat cells. In this context, MSNsP inhibited $\sim 12 \%$ compared to MSNs $\sim 7 \%$ at $1000 \mu \mathrm{g} / \mathrm{mL}$. Figure 7B shows that MSNsPCOL/CG-FA inhibited $90 \%$ more than COL at $50 \mu \mathrm{g} / \mathrm{mL}$. Thus, the developed DDS is the most likely reason for enhanced tubulin inhibition because of the COL tubulin inhibitor agent $[5,48,49]$. We propose that the action for MSNsPCOL/CG-FA is the release of COL molecules into cells after folate receptor-folic acid interaction; the COL binds to tubulin in cells through colchicine binding sites, destabilizing tubulin [50], and further interferes with microtubule dynamics. 
The later response causes effective mitotic action against HCT116 cells. Further post-antimitotic response can arrest the cell cycle at the G2/M phase [51] and cause apoptotic cell death [52].
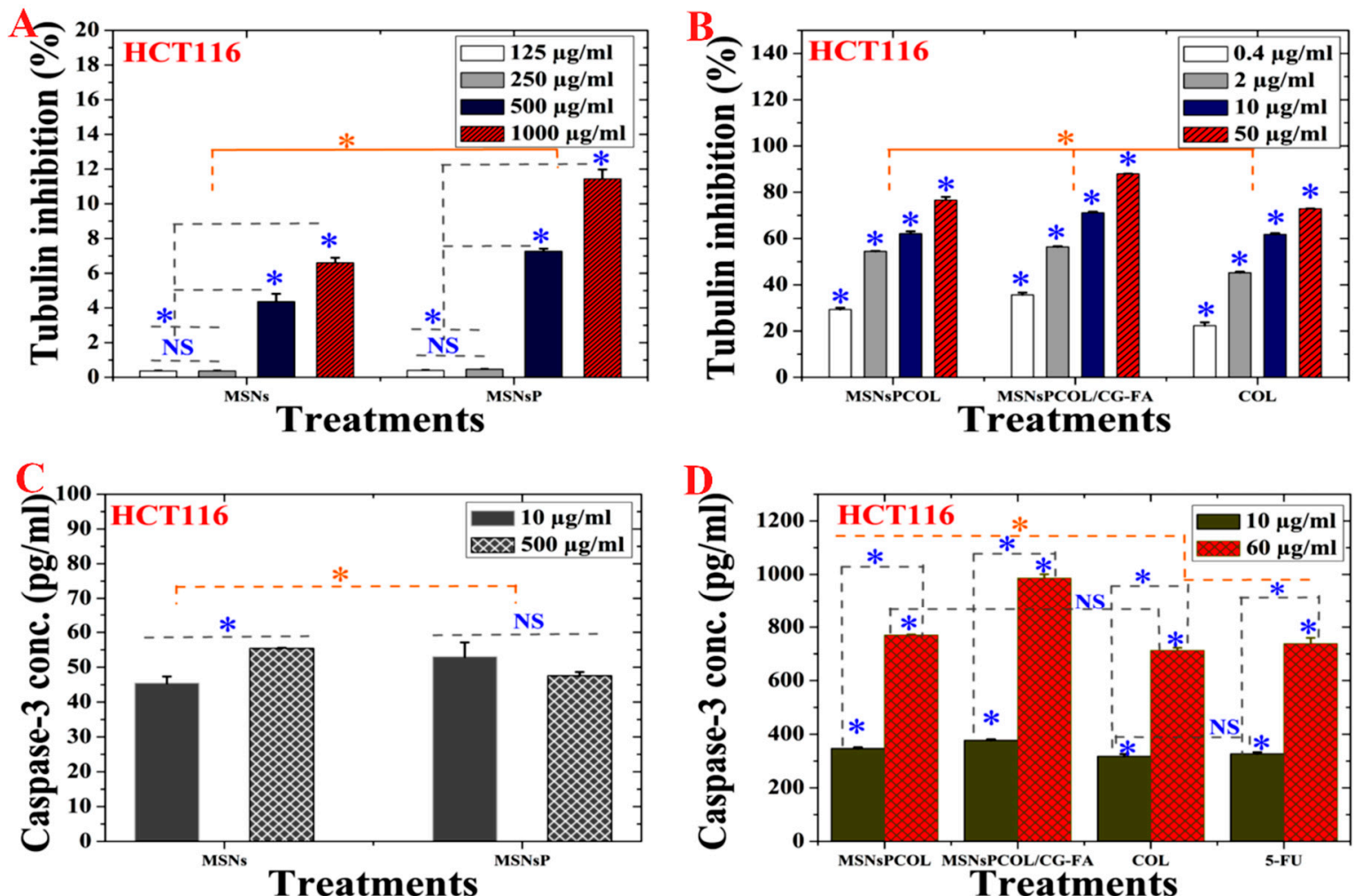

Figure 7. (A) Tubulin inhibition activity of HCT116 cells treated with MSNs and MSNsP as a function of concentration. (B) Tubulin inhibition activity HCT116 cells treated with the proposed delivery system as a function of concentration. (C) Caspase-3 activity of HCT116 cells treated with MSNs and MSNsP as a function of concentration. (D) Caspase-3 activity of HCT116 cells treated with the proposed delivery system and compared to the model anticancer drug (5-FU) as a function of concentration. Note: A blue asterisk $(*)$ indicates significant $(p<0.05)$ differences between tested concentrations, whereas an orange asterisk $\left(^{*}\right)$ indicates significant differences between tested samples. NS, not significant. All data are expressed as mean $\pm \mathrm{SD}$.

\subsection{Cell Cycle Arrest at the G2/M Phase in HCT116 Cancer Cells}

The G2/M checkpoint inhibitor class of drugs leads to DNA damage, preventing cells from passing mitosis and stopping their proliferation. As a result, cells cannot enter mitosis prior to repairing their DNA damage, resulting in apoptosis or death after their division [53] through various molecular signaling pathways $[54,55]$. Several reports have demonstrated that COL can arrest at G2/M in different cancer cells $[7,56]$.

The cell cycle analysis was dependent on incubation time (Figure S2A,B in Supplementary Information). After $24 \mathrm{~h}, \mathrm{MSNsPCOL/CG-FA} \mathrm{resulted} \mathrm{in} \mathrm{the} \mathrm{maximum} \mathrm{accumulation} \mathrm{of} \mathrm{cells} \mathrm{at} \mathrm{G2/M}$ (14.8\%), followed by 5-FU (12.4\%), MSNsPCOL (11.2\%), and COL (8.7\%), with the lowest accumulation for MSNs (4.9\%), MSNsP (4.8\%), and untreated control (4.76\%). In contrast, accumulation of cells at $\mathrm{S}$ phase was inhibited by MSNsPCOL/CG-FA (18.8\%), MSNsPCOL (21.1\%), 5-FU (21.2\%), COL (23.3\%), MSNsP (27.4\%), and MSNs (27.6\%) compared to control (27.7\%). After $72 \mathrm{~h}$, the number of cells increased at G2/M and deceased at $\mathrm{S}$ phase compared to $24 \mathrm{~h}$. This cycle analysis pattern shows the endorsement of HCT116 cancer cell arrest at G2/M phase together with evidence that cells could not enter the $S$ phase. 


\subsection{Enhancement of Apoptosis Induction in HCT116 Cancer Cells}

Apoptosis is a distinct or intrinsic occurrence relating to different physiological and pathological responses [55] and usually contributes to efficient antitumor action for most anticancer drugs [54,57]. To investigate whether the treatments induce apoptosis, HCT116 cells were stained with Annexin V-FITC and propidium iodide (PI), and then analyzed by flow cytometry. The parameters of late apoptosis, early apoptosis, and necrosis were quantified. Total apoptosis induction (early plus late) increased with treatment compared to untreated control cells after $72 \mathrm{~h}$ compared to $24 \mathrm{~h}$ (Figure S3A,B in Supplementary Information). The effects on total apoptosis were in this order: MSNsPCOL/CG-FA $(15.0 \%)>\operatorname{MSNsPCOL}(14.2 \%)>5$-FU $(13.2 \%)>\operatorname{COL}(10.6 \%)>\operatorname{MSNsP}(0.5 \%)>\operatorname{MSNs}(0.43)$. Compared to untreated control (0.5\%), MSNs and MSNsP had no effects on apoptosis, reflecting the importance of DDS other than COL and 5-FU drugs. In addition to the induction of apoptosis, MSNsPCOL/CG-FA had a $1.4 \%$ necrosis effect. As MSNsPCOL/CG-FA promoted apoptosis (early and late apoptosis) (Figure 8B), the G2/M arrest triggers apoptosis in HCT116 cancer cells [58,59].
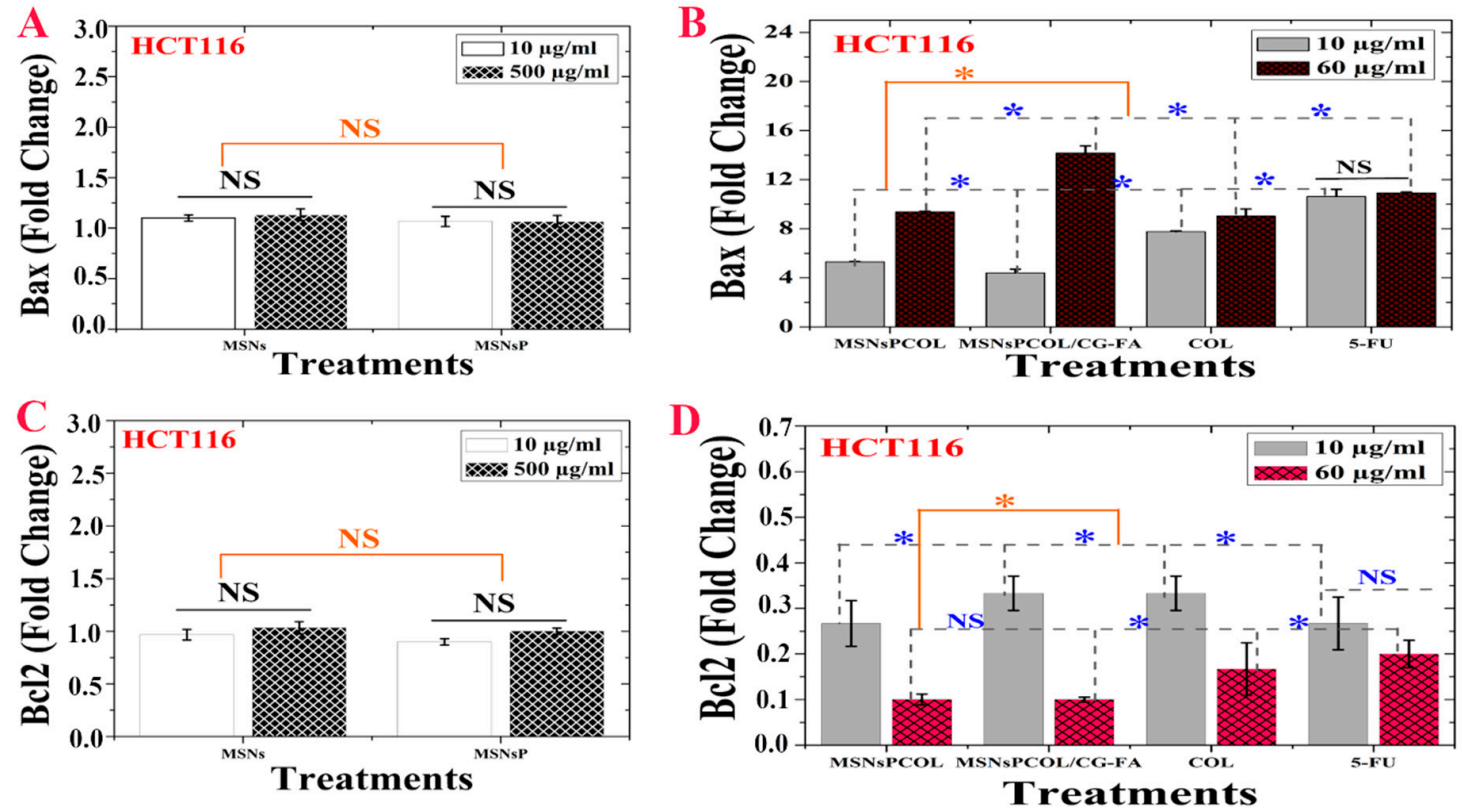

Figure 8. (A) Bax activity of HCT116 cells treated with MSNs and MSNsP as a function of concentration. (B) Bax activity of HCT116 cells treated with the proposed delivery system and compared to the model anticancer drug (5-FU) as a function of concentration. (C) Bcl-2 inhibition activity of HCT116 cells treated with MSNs and MSNsP as a function of concentration. (D) Bcl-2 inhibition activity of HCT116 cells treated with the proposed delivery system and compared to the model anticancer drug (5-FU) as a function of concentration. Note: A blue asterisk $\left(^{*}\right)$ indicates significant $(p<0.05)$ differences between tested concentrations, whereas an orange asterisk $\left(^{*}\right)$ indicates significant differences between tested samples. NS, not significant. All data are expressed as mean \pm SD.

\subsection{Activation of Caspase-3 in HCT116 Cancer Cells}

The activation of intracellular caspase is one of the main characteristics of the apoptosis cell death pathway leading to the cleavage and inactivation of many cellular proteins, leading to the occurrence of apoptotic cell death in most cancer cell types [60]. As shown in Figure 7C, a significant effect was detected among MSNs and MSNsP. Treatment of cells with $500 \mu \mathrm{g} / \mathrm{mL}$ MSNs significantly increased activity compared to $10 \mu \mathrm{g} / \mathrm{mL}$. In contrast, no significant differences were detected in either concentrations of MSNsP. Maximal activation of both treatments did not reach $>55 \mathrm{pg} / \mathrm{mL}$, which is a low enhancement effect. The caspase-3 activity was dependent on concentration and delivery method (Figure 7D), with high activity resulting from increased concentration to $60 \mu \mathrm{g} / \mathrm{mL}$ compared to $10 \mu \mathrm{g} / \mathrm{mL}$. Maximal caspase-3 activity (>1000 pg/mL) was recorded for MSNsPCOL/CG-FA. Caspase-3 
activation was enhanced in this order: MSNsPCOL/CG-FA $>$ MSNsPCOL $>$ 5-FU $>$ COL. These results agree with our previous results using MSNs [26,27].

\subsection{Modulation of Proapoptotic Bax/Bcl-2 in HCT116 Cancer Cells}

Figure $8 \mathrm{~A}$ shows no significant effect of MSNs and MSNsP on Bax, but these nanoparticles enhanced it to a little over 1 FLD. Figure 8B shows the significant difference for Bax at $60 \mu \mathrm{g} / \mathrm{mL}$ compared to $10 \mu \mathrm{g} / \mathrm{mL}$. In addition, MSNsPCOL/CG-FA enhanced Bax to 14 FLD, and the enhancement ranked in the following order: MSNsPCOL/CG-FA > 5-FU > COL > MSNsPCOL. In particular, MSNsPCOL/CG-FA strongly enhanced Bax compared to the clinically used 5-FU drug.

Though MSNs and MSNsP had not significant effect, they slightly inhibited BCL-2 1.2 FLD (Figure 8C). As shown in Figure 8D, the inhibition of BCL-2 was affected by concentration. Treatment of cells at $10 \mu \mathrm{g} / \mathrm{mL}$ resulted in low inhibition and ranked in effect as follows: MSNsPCOL and 5-FU $(>0.2$ FLD) $>$ MSNsPCOL/CG-FA and COL ( 0.35 FLD). Upon further increasing the concentration to $60 \mu \mathrm{g} / \mathrm{mL}, \mathrm{BCL}-2$ highly inhibited to $\sim 0.1 \mathrm{FLD}$ (for MSNsPCOL/CG-FA and MSNsPCOL), $<0.2 \mathrm{FLD}$ (for $\mathrm{COL}$ ), and $\sim 0.2 \mathrm{FLD}$. These findings show significantly better molecular targeting of nanoformulations in HCT116 cells via Bax enhancement and BCL-2 inhibition than free COL and 5-FU. Furthermore, this effect strongly requires efficient upregulation of Bax and down-regulation of BCL-2, allowing progression of the apoptotic pathway in HCT116 cancer cells. Inhibition of BCL-2 is important because it is considered a potent death suppressor protein; it promotes cell survival by blocking apoptosis and is upregulated in several cancers. BCL-2 is classified as an anti-apoptotic protein in many cancers, including colorectal cancer [61,62], inducing cancer resistance to drugs. Bax is a pro-apoptotic protein that promotes apoptosis in cells but is always present in inactivated states in many cancers, including colon cancer $[57,63]$. Therefore, these results confirm that the enhancement of apoptosis by MSNsPCOL/CG-FA interconnects with reduced Bcl-2 and increased Bax.

\subsection{Inhibition of BRAF Expression in HCT116 Cancer Cells}

Colon cancer is associated with multiple processes through various genetic alterations [64], including RAF genes, which mediate several cellular responses [65]. They contribute to carcinogenesis by upregulating the anti-apoptotic RAS/RAF/MEK/ERK pathway [66]. High expression of BRAF (anti-apoptotic protein) inhibits apoptosis by activating the BRAF/MEK/ERK route, which interferes with apoptosis through reduction of caspase and cytochrome c [67].

BRAF inhibition was concentration- and time-dependent. MSNs and MSNsP (at $1000 \mu \mathrm{g} / \mathrm{mL}$ ) reduced BRAF $\sim 3 \%$ to $3.5 \%$ for cells incubated for 24 and $48 \mathrm{~h}$, respectively (Figure $9 \mathrm{~A}, \mathrm{~B}$ ). Significant inhibition of BRAF was dependent on concentration, time, and delivery route (Figure 9C,D). It was decreased in cells incubated for a longer time. For example, at $50 \mu \mathrm{g} / \mathrm{mL}$ treatment, the inhibition was $\sim 90 \%, \sim 87 \%, \sim 82 \%$, and $\sim 80 \%$ with MSNsPCOL/CG-FA, MSNsPCOL, COL, and 5-FU, respectively. This pattern shows that MSNsPCOL/CG-FA is efficient in inhibiting BRAF in HCT116 cells. Our findings on MSNsPCOL/CG-FA confirm the killing of HCT116 cancer cells was enhanced through apoptosis mechanisms. 

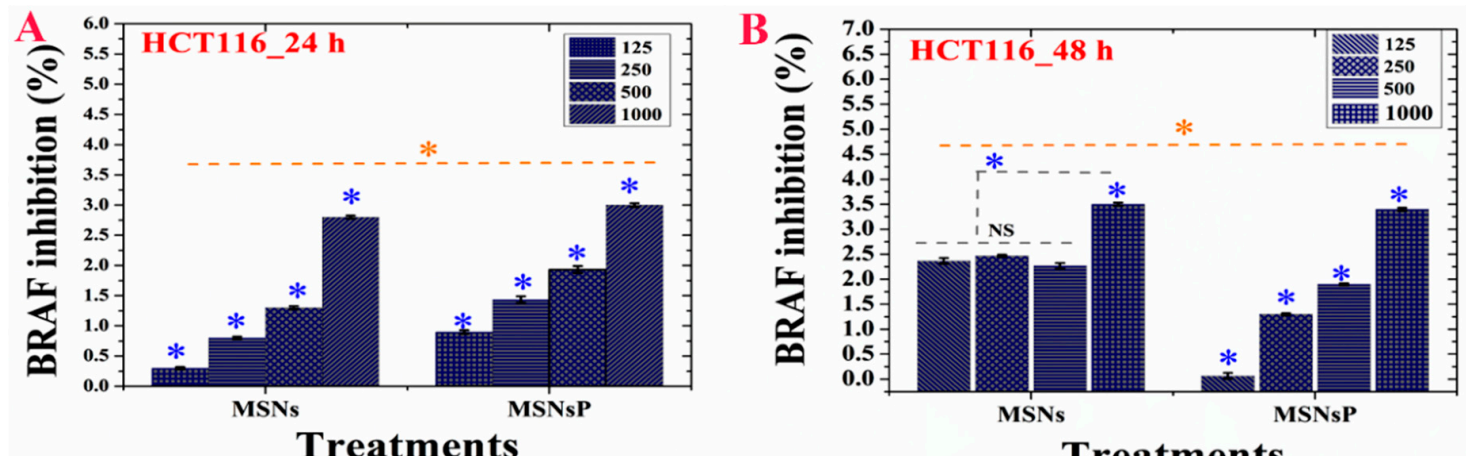

Treatments
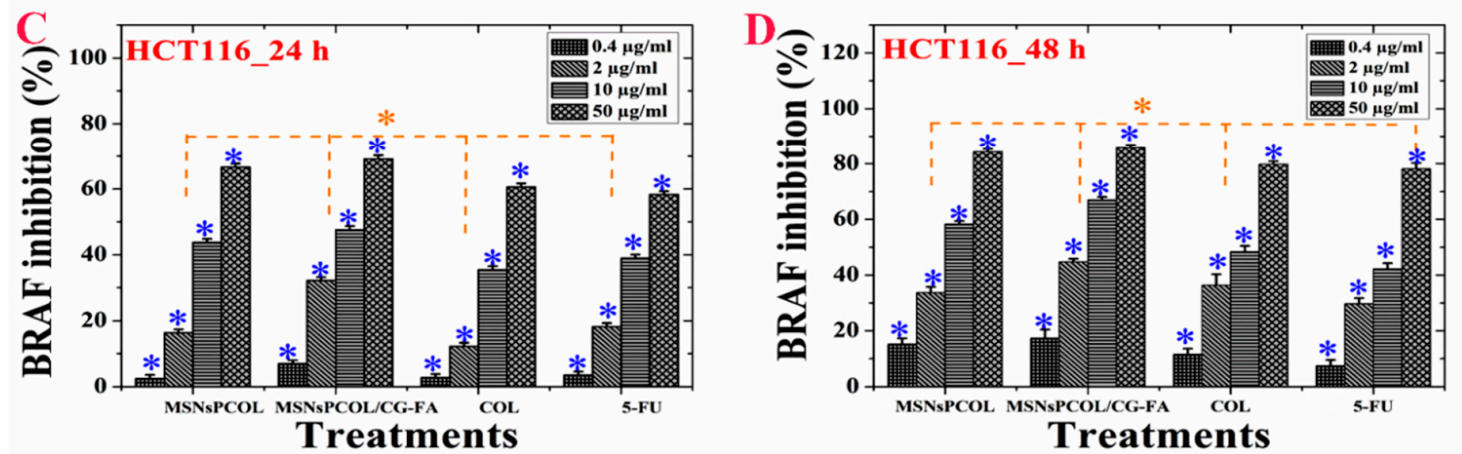

Figure 9. (A) BRAF activity of HCT116 cells treated with MSNs and MSNsP as a function of concentration. (B) BRAF activity of HCT116 cells treated with the proposed delivery system and compared to the model anticancer drug (5-FU) as a function of concentration. (C) BRAF inhibition activity of HCT116 cells treated with MSNs and MSNsP as a function of concentration. (D) BRAF inhibition activity of HCT116 cells treated with the proposed delivery system and compared to the model anticancer drug (5-FU) as a function of concentration. Note: A blue asterisk $\left.{ }^{*}\right)$ indicates significant $(p<0.05)$ differences between tested concentrations, whereas an orange asterisk $\left(^{*}\right)$ indicates significant differences between tested samples. All data are expressed as mean \pm SD.

\subsection{Enhancement of Cytochrome c Triggers in HCT116 Cancer Cells}

As shown in Figure 10A, no significant effect was detected for MSNs and MSNsP treated at $500 \mu \mathrm{g} / \mathrm{mL}$ for $72 \mathrm{~h}$. Significant effect was detected in HCT116 cells treated with the nanoformulations compared to COL (Figure 10B). Triggering of cytochrome $\mathrm{c}$ was found in this order: MSNsPCOL/CG-FA $>$ MSNsPCOL $>$ COL $>5$-FU. Our results agree with the results by Zhang et al. that COL triggers cytochrome $\mathrm{c}$ from the mitochondria to the cytoplasm in human gastric cancer cells [68]. These results confirm that the delivery system for COL activates apoptosis via the intrinsic apoptotic signaling pathway.

\subsection{Reduction of Mitochondrial Membrane Potential in HCT116 Cancer Cells}

No significant effect was observed among MSNs and MSNsP treated at $500 \mu \mathrm{g} / \mathrm{mL}$ for $72 \mathrm{~h}$ (Figure 10C). Importantly, treatment of HCT116 cells with MSNsPCOL/CG-FA significantly decreased mitochondrial membrane potential compared to MSNsPCOL, COL, 5-FU, and control (Figure 10D). Minimal mitochondrial membrane potential was found in this order: MSNsPCOL/CG-FA < 5-FU < COL $<$ MSNsPCOL. It was reported that free COL decreased mitochondrial membrane potential in HT-29 colon cells, which led to intrinsic apoptotic cell death [6]. 


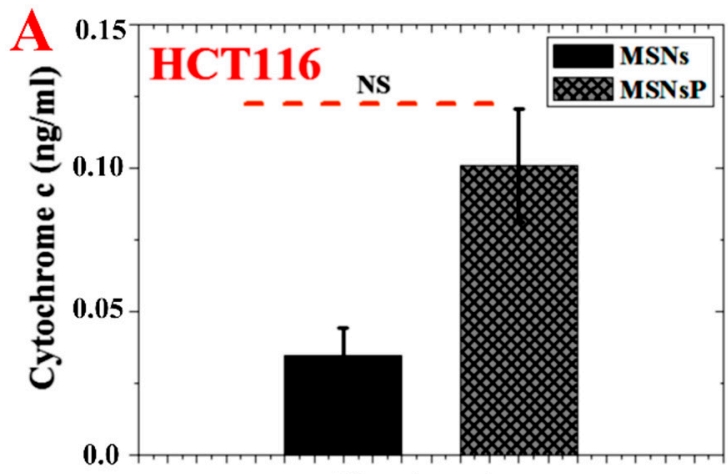

Treatments

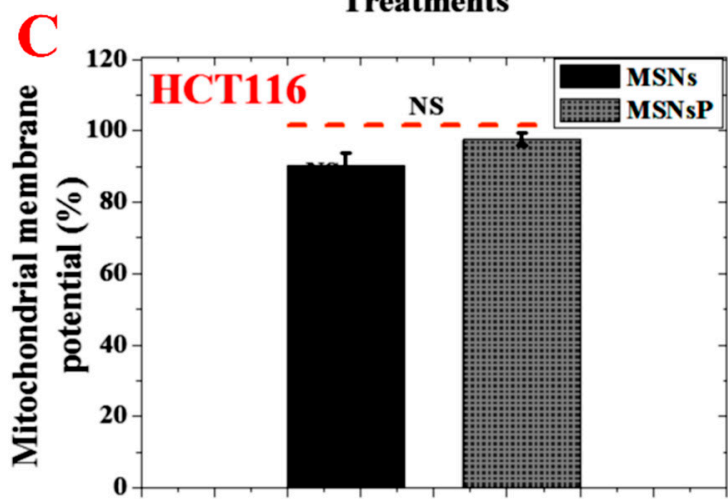

Treatments

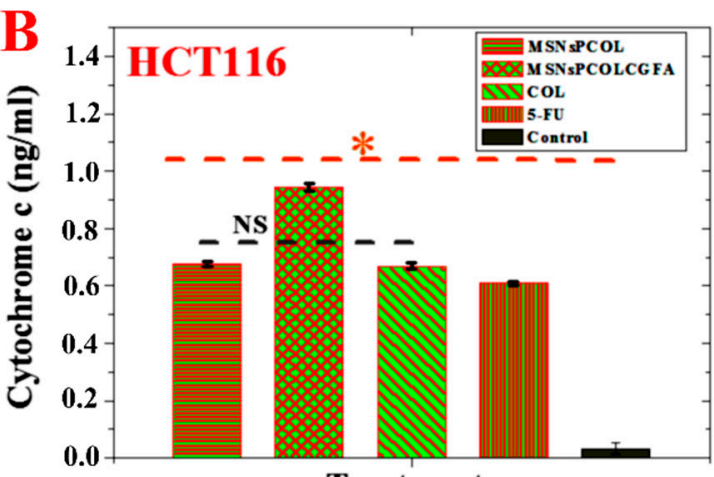

Treatments

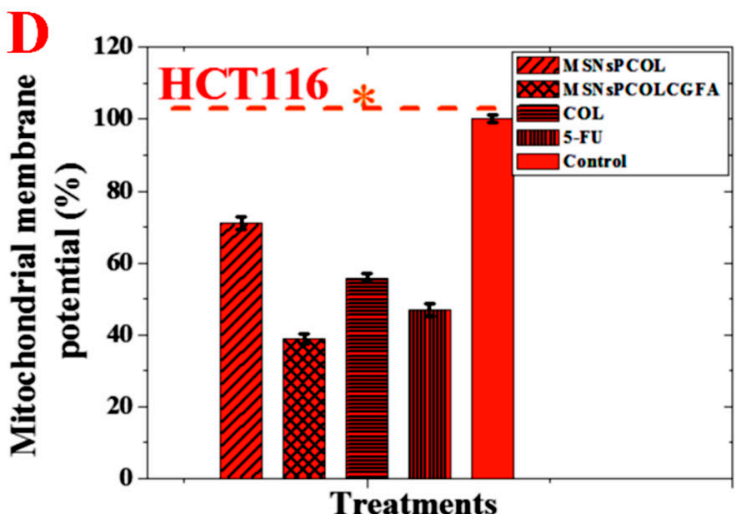

Figure 10. (A) Cytochrome c triggering of HCT116 cells treated with MSNs and MSNsP at $500 \mu \mathrm{g} / \mathrm{mL}$. (B) Cytochrome c triggering of HCT116 cells treated at $60 \mu \mathrm{g} / \mathrm{mL}$ with the proposed delivery system for $72 \mathrm{~h}$ and compared to the model anticancer drug (5-FU) and control (without any treatment). (C) Mitochondrial membrane potential $(\Delta \psi \mathrm{m})$ of HCT116 cells treated with MSNs and MSNsP at $500 \mu \mathrm{g} / \mathrm{mL}$. (D) Mitochondrial membrane potential of HCT116 cells treated at $60 \mu \mathrm{g} / \mathrm{mL}$ with the proposed delivery system for $72 \mathrm{~h}$ and compared to the model anticancer drug (5-FU) and control. Note: An orange asterisk $(*)$ indicates significant $(p<0.05)$ differences between tested samples. NS, not significant. All data are expressed as mean \pm SD.

\subsection{Inhibition of CD44 Expression in HCT116 Cancer Cells}

As CD44 is a transmembrane glycoprotein, it can take part in different cellular processes, including growth, survival, cell differentiation, resistance to apoptosis [69-71], and tumorigenesis of colon cancer, such as HCT-116 cells [72]. CD44 is well-recognized as a robust marker (via overexpression) of colon cancer initiation because it promotes cell adhesion, maintains cell-matrix interactions [73], and induces anti-apoptotic properties [71,74]. Therefore, CD44 is a potential therapeutic target in colon cancer.

MSNsPCOL/CG-FA, MSNsPCOL, and COL highly attenuated the CD44 concentration in HCT116 compared to positive control cells $(185.5 \pm 15.4 \mathrm{ng} / \mathrm{mL}$; Figure $11 \mathrm{~A})$. We found no significant differences between MSNsPCOL/CG-FA $(33.3 \pm 3.5 \mathrm{ng} / \mathrm{mL})$, MSNsPCOL $(34.1 \pm 3.3 \mathrm{ng} / \mathrm{mL})$, and COL $(37.3 \pm 3.2 \mathrm{ng} / \mathrm{mL})$. However, they significantly inhibited CD44 compared to 5-FU $(63.7 \pm 8.5 \mathrm{ng} / \mathrm{mL})$. Concerning the anti-apoptotic effect of CD44 expression in colon cancer, Lakshman et al. previously reported that it prevents the apoptosis killing pathway because it promotes cell transformation into a malignant phenotype with the help of other anti-apoptotic factors in the tumor microenvironment [75]. We recorded the maximum inhibition for MSNsPCOL/CG-FA, supporting the results obtained for apoptosis induction. In a previous study of colon cancer cells, Park et al. reported that knockdown of CD44 leads to inhibition of cell proliferation and induction of apoptosis [71]. 

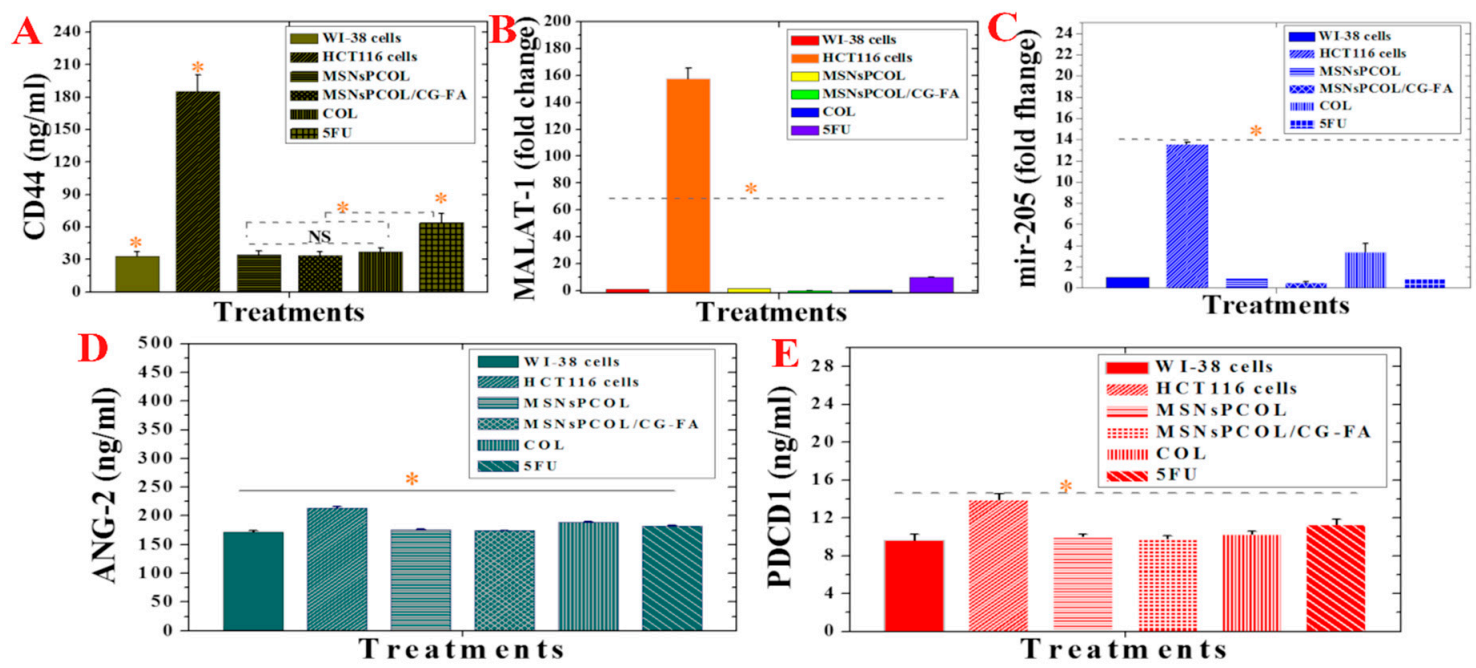

Figure 11. (A) MALAT-1 protein expression in normal WI-38 cells, HCT116 cells, and HCT116 cells treated with proposed delivery and 5-FU. (B) mir-205 expression in normal WI-38 cells, HCT116 cells, and HCT116 cells treated with proposed delivery and 5-FU. (C) Ang-2 protein expression in normal WI-38 cells, HCT116 cells, and HCT116 cells treated with proposed delivery and 5-FU. (D) CD44 protein expression in normal WI-38 cells, HCT116 cells, and HCT116 cells treated with proposed delivery and 5-FU. (E) PD-1 protein expression in normal WI-38 cells, HCT116 cells, and HCT116 cells treated with proposed delivery and 5-FU. Note: An orange asterisk $\left.{ }^{*}\right)$ indicates significant $(p<0.05)$ differences between tested samples, whereas a blue asterisk $\left(^{*}\right)$ indicates significant differences between specific samples. NS, not significant. All data are expressed as mean \pm SD.

\subsection{Inhibition of MALAT-1 Expression in HCT116 Cancer Cells}

In recent years, emerging indications are that lncRNAs, non-protein coding transcripts longer than 200 nucleotides, are responsible for a broad spectrum of biological impacts with gene regulation and other functions in many diseases [76,77]. Among others, MALAT1 increases tumor formation in many cancers, including gastric, gallbladder, and lung cancer in vivo [77-80]. Importantly, MALAT1 has been shown in several studies to promote colorectal cancer cell development via proliferation, migration, and invasion [81,82], and is considered a potential therapeutic target for colon cancer. MALAT-1 was significantly inhibited by all delivery methods and free drugs (Figure 11B) compared to positive control cells. MSNsPCOL/CG-FA had a maximum inhibition effect with $0.3 \pm 0.05$-fold change, followed by COL ( $0.46 \pm 0.05$-fold change), MSNsPCOL ( $1.5 \pm 0.15$-fold change), and 5-FU (10.06 \pm 0.57 -fold change) compared to positive control cells ( 160 -fold change). Importantly, when HCT116 cells were treated with MSNsPCOL/CG-FA, the inhibition level was close to the level of normal cells. These results point out that COL and its nanoformulations are more efficient than 5-FU in hindering the expression of MALAT- 1 in HCT116 cells, which is necessary for therapeutic targeting of colon cancer. To the best of our knowledge, no data are available yet on the effects of COL on MALAT1 inhibition or promotion.

\subsection{Attenuation of mir-205 Expression in HCT116 Cancer Cells}

Micro-RNAs are small non-coding RNAs discovered in 1993 that play crucial roles in cancer, including in cell viability, proliferation, invasion, metastasis, tumor suppressors, and oncogenes [83,84], allowing them to be used in cancer diagnosis and treatment $[85,86]$. Jing et al. showed that the expression of mir-205 is upregulated in plasma from colon cancer patients, permitting the occurrence and development of the cancer. Thus, mir-205 may be a potential tumor marker and therapeutic target [87]. However, mir-205 has also been reported to be downregulated in colon cancer [88].

Treating HCT116 cells with MSNsPCOL/CG-FA, MSNsPCOL, 5-FU, and COL decreased mir-205 expression. The inhibition values were $0.53 \pm 0.05,0.97 \pm 0.05,10 \pm 0.3$, and $3.4 \pm 0.7$-fold change, 
respectively, compared to the 14 -fold change in positive control cells. This provides of evidence of possible mir-205 targeting in colon cancer (Figure 11C). To the best of our knowledge, there are no data available yet on the effects of COL in either downregulating or upregulating mir-205 in cancer. Our results may pave the way for further deep investigations.

\subsection{Inhibition of Ang-2 Expression in HCT116 Cancer Cells}

One characteristic of cancer is pathological angiogenesis, which plays a crucial role in selecting a therapy. Ang-2 is a pro-angiogenic cytokine that maintains angiogenesis and restricts the antitumor immune response from attacking cancer cells. In a study by Schmittnaegel et al., inhibition of Ang-2 together with vascular endothelial growth factor A (VEGFA) enhanced the antitumor immunity, allowing PD-1 checkpoint inhibition [89]. In addition, Kim et al. indicated that Ang-2 maybe play a crucial role as an oncogene in colorectal carcinogenesis, supporting tumor progression as a prognostic marker [90]. Therefore, we sought to explore the proposed DDS for the possibility of inhibiting Ang-2 and further explain the PD-1 checkpoint inhibitor.

A significant difference was detected between all treatments and positive control cells (HCT116 cells with no treatment; Figure 11D). Notably, treated HCT116 cells had strongly inhibited expression of Ang-2, which was slightly like its expression level in normal cells (172.1 \pm 2.5$)$. A maximum inhibition of Ang-2 recorded for MSNsPCOL/CG-FA $(174.0 \pm 0.75 \mathrm{ng} / \mathrm{mL})>$ MSNsPCOL $(175.7 \pm 1.0 \mathrm{ng} / \mathrm{mL})>5-\mathrm{FU}$ $(182.3 \pm 1.15 \mathrm{ng} / \mathrm{mL})>$ COL $(188.6 \pm 1 \mathrm{ng} / \mathrm{mL})$ compared to positive control cells $(213.3 \pm 3.0 \mathrm{ng} / \mathrm{mL})$. These results suggest that the anticancer activity of the proposed DDS could promise to target Ang-2 supporting the immune checkpoints inhibition [89,91].

\subsection{Inhibition of PD-1 Expression in HCT116 Cancer Cells}

Figure 11E shows the suppression of PD-1 checkpoint with significant changes compared control cells; the maximum inhibition level was reached at $9.8 \pm 0.3 \mathrm{ng} / \mathrm{mL}$ and $10 \pm 0.3 \mathrm{ng} / \mathrm{mL}$ for MSNsPCOL/CG-FA and MSNsPCOL, respectively, compared to $14 \pm 0.5 \mathrm{ng} / \mathrm{mL}$ with positive control cells. This was similar to the PD-1 concentration in normal BJ1 cells $(9.6 \pm 0.5)$, which is significant. PD-1 reached $10.3 \pm 0.2$ and $11.2 \pm 0.5$ with free COL and 5-FU, respectively.

Recent studies have revealed the intrinsic expression of PD-1 in many cancers, along with $\mathrm{T}$ immune cells [20,21]. Therefore, it is considered as a new potential for cancer therapy [19] and efficient treatments [92]. Checkpoint blockade immunotherapy has revolutionized treatment for tumors and, in the next years, scientists are expected to focus on immunotherapy research and broaden its scope to target cancers by different strategies [22]. PD-1 immune checkpoint inhibitors act by blocking the PD-1 protein and activate the immune system to treat many tumors [22,93]. MSNsPCOL/CG-FA inhibited PD-1 in HCT116 cells to the range close to normal BJ1 cells, which is important. These are the first results for COL or a DDS as a small drug molecule. PD-1 inhibitors are usually large molecules, such as antibodies, antigens, peptides, and therapeutic proteins. Although many approved therapies are efficient in cancer (e.g., nivolumab and pembrolizumab), they have many limitations, including side effects, toxicity, internal response changes in the immune system, and expense [94,95]. The results create an opportunity to develop a new approach of PD-1 inhibitors through further ongoing research.

In summary, the main findings in the current study were enhancement of the antimitotic effects of COL by means of a targeted delivery system (MSNsPCOL/CG-FA). The enhanced antimitotic effects block cancer cell growth due to the binding of COL to tubulin in cells, leading to cell death. The main mechanism of action is an apoptosis cell death mechanism through different molecular pathways known for COL action on cancer cells. In addition, genetic regulation and immunotherapeutic effects have a role. A schematic representation of the nanoformulation mechanism of action is shown in Figure 12, and Table 2 outlines the results of the current study. The following factors explain the feasibility of cancer-targeting via folate receptors using folic acid ligands as developed here:

(1) The developed nano-delivery system efficiently targets the interaction of folic acid (on the surface of MSNsPCOL/CG-FA) with folate receptors over-expressed on cancer cells. In a next step, it 
releases COL into cancer cells, which can bind to the tubulin forming the microtubules in the cellular skeleton, resulting in tubulin inhibition. This effect is important because microtubules enable cells to undergo mitosis or subsequent intracellular post-antimitotic responses. Maximum tubulin inhibition ( 90\%) was achieved when HCT116 cancer cells were treated with MSNsPCOL/CG-FA.

(2) By producing the antimitotic effect via tubulin inhibition, the cells died. The cell-killing was cell line-, concentration-, time-, and delivery method-dependent. We observed that HCT116 cells were more sensitive to treatments than HepG2 and PC3 cells. In the case of HepG2 and PC3 cells, MSNsPCOL/CG-FA efficiently inhibited the cells compared to COL at all concentrations used. In the case of HCT116 colon cells, a strong effect was observed when incubating cells for $72 \mathrm{~h}$. MSNsPCOL/CG-FA and COL had equal inhibition (100\%) at $200 \mu \mathrm{g} / \mathrm{mL}$. At lower concentrations, MSNsPCOL/CG-FA significantly inhibited HCT116 cells compared to COL. Thus, at all concentrations, MSNsPCOL/CG-FA was more efficient than COL in HCT116 cells. Concerning IC50, MSNsPCOL/CG-FA had a lower value $(17.0 \mu \mathrm{g} / \mathrm{mL})$ than free COL after $72 \mathrm{~h}$. In addition, MSNsPCOL/CG-FA had less toxicity towards normal cells $(10 \%)$ than COL $(60 \%)$.

(3) Because COL inhibits tubulin, the post-antimitotic response resulted in various molecular pathways, including cell-cycle arrest, apoptosis, and genetic regulation [14]. We investigated several molecular, genetic, and immunology pathways to explore the mechanism of action. The results confirm that tubulin was markedly inhibited, especially with MSNsPCOL/CG-FA compared to COL. Because of the inhibition of tubulin and the resulting cell cycle arrest, we investigated cell cycle analysis by flow cytometry. MSNsPCOL/CG-FA enhanced the cell-cycle arrest at G2/M phase compared to COL. This observation confirms the tubulin inhibition effect. Arresting cells at the G2/M phase results in apoptosis. The maximum induction of apoptosis was detected for MSNsPCOL/CG-FA. Therefore, this observation confirms that the apoptosis cell death mechanism occurs in HCT116 cancer cells. To further confirm whether apoptosis is the main mechanism of action, we tested many molecular pathways. We observed that caspase-3 was enhanced when cells were treated with MSNsPCOL/CG-FA compared to other formulation, and this is one of the main routes for apoptosis. The modulation of pro-apoptotic proteins is shared with apoptosis; treating cells with MSNsPCOL/CG-FA promoted Bax and inhibited Bcl-2 protein. The anti-apoptotic BRAF protein and CD44 cellar protein levels were highly inhibited after cells were treated with MSNsPCOL/CG-FA. The observations provide strong evidence of the intrinsic apoptosis mechanism due to enhanced cytochrome $\mathrm{c}$ triggering and reduce the mitochondrial membrane potential, in agreement with the literature.

(4) New effects were obtained in our study. The antimitotic drugs act by inducing various genetic regulations that may or may not be related to the apoptosis mechanism. Our results show that MSNsPCOL/CG-FA inhibited MALAT 1 and mir-205 in treated cells. Regarding the importance of cancer immunotherapy because of the post-antimitotic effects, MSNsPCOL/CG-FA markedly inhibited Ang-2 protein and PD-1 in HCT116 cancer cells compared to normal WI-38 cells. To the best of our knowledge, the results for MALAT1, mir-205, and PD-1 with COL and its delivery in HCT116 cancer cells were obtained for the first time. The findings suggest that the killing of cancer cells is in response to the effects of the post-antimitotic response of the COL delivery route. We propose that the anticancer mechanism is mainly apoptosis cell death, with the contribution of genetic regulation and immunotherapy effects. 


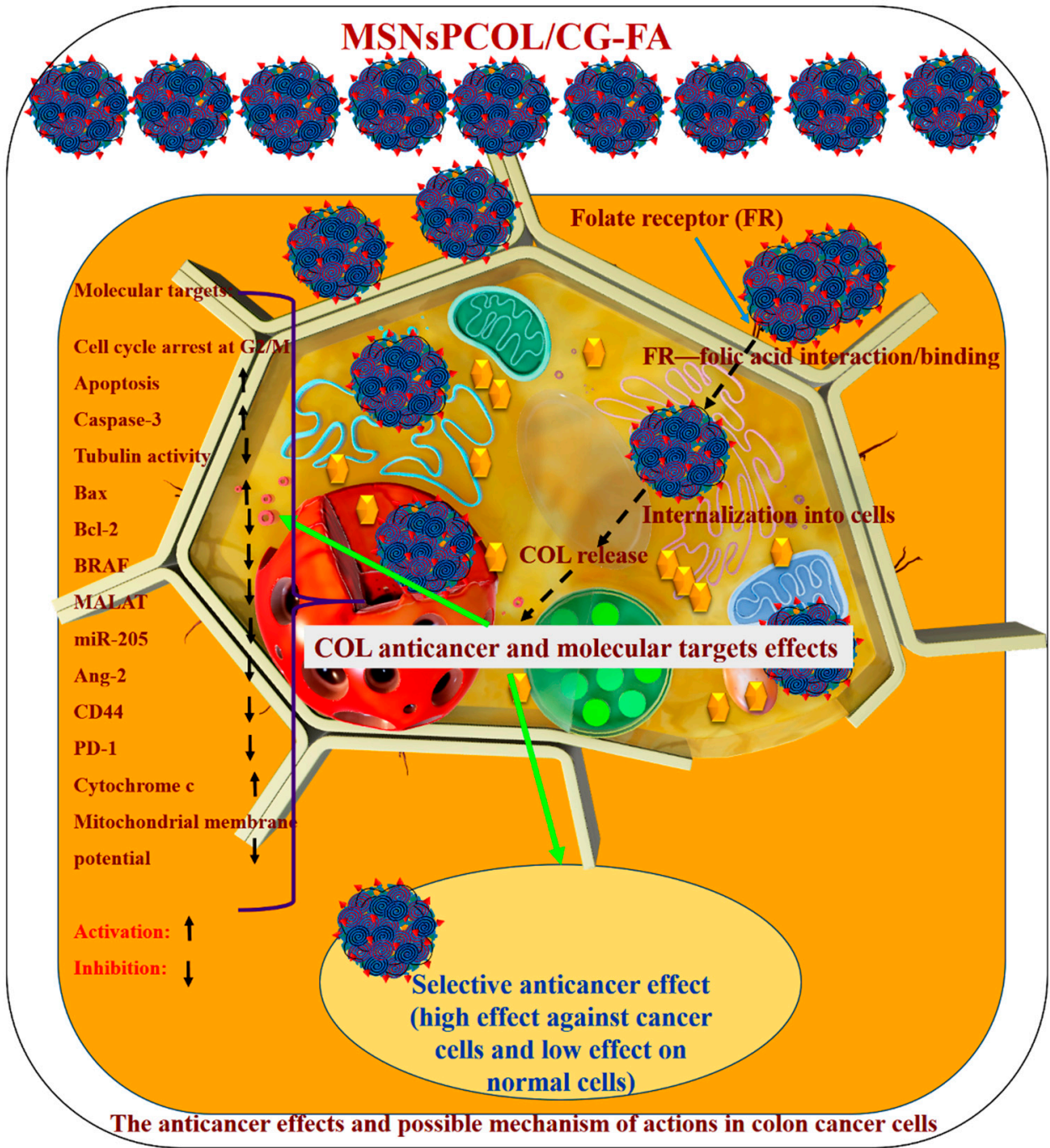

Figure 12. Schematic representation of cancer cell killing and possible anticancer mechanisms by which the proposed drug delivery system for colchicine (MSNsPCOL/CG-FA nanoformulation) acts in vitro against HCT116 colon cancer cells.

Table 2. Summary of the results obtained for colchicine (COL) delivery methods.

\begin{tabular}{|c|c|c|c|}
\hline $\begin{array}{c}\text { Colchicine Delivery } \\
\text { Method }\end{array}$ & Structure & $\begin{array}{c}\text { Cancer and } \\
\text { Normal Cell Lines }\end{array}$ & Targeting Specifications \\
\hline COL (free) & & $\begin{array}{l}\text { Normal cell line } \\
\text { Cancer cell lines }\end{array}$ & $\begin{array}{c}\text { High cytotoxicity }(\sim 60 \%) \\
\text { High anticancer effect at high concentration } \\
\text { Non-targeting }\end{array}$ \\
\hline \multicolumn{4}{|c|}{ Colchicine } \\
\hline $\begin{array}{l}\text { MSNsPCOL } \\
\text { COL-loaded silica } \\
\text { spheres }\end{array}$ & & $\begin{array}{l}\text { Normal cell line } \\
\text { Cancer cell lines }\end{array}$ & $\begin{array}{l}\text { Less cytotoxicity }(\sim 15 \%) \\
\text { High anticancer effect } \\
\text { Not enough cancer targeting }\end{array}$ \\
\hline $\begin{array}{l}\text { MSNsPCOL/CG-FA } \\
\text { COL-loaded silica } \\
\text { spheres coated with } \\
\text { chitosan and glycine and } \\
\text { conjugated to folic acid }\end{array}$ & & $\begin{array}{l}\text { Normal cell line } \\
\text { Cancer cell lines }\end{array}$ & $\begin{array}{c}\text { Negligible cytotoxicity }(\sim 5 \%) \\
\text { High anticancer effect } \\
\text { High cancer-targeting } \\
\text { Specific killing of } \\
\text { HCT116 colon cancer (achieved 100\% inhibition), PC3 } \\
\text { prostate, and HepG2 liver cells ( } \sim 80 \% \text { inhibition) } \\
\text { Cancer targeting through folate receptors } \\
\text { Enhanced apoptosis mechanism, genetic regulation, } \\
\text { and cancer immunotherapy effects }\end{array}$ \\
\hline
\end{tabular}




\section{Materials and Methods}

\subsection{Materials}

COL, 5-fluorouracil (5-FU), tetraethyl orthosilicate (TEOS), cetylpyridinium bromide (CPB), cyclohexane, isopropanol, urea, glycine, folic acid, insulin, penicillin G, streptomycin, and MTT assay kits were purchased from Sigma-Aldrich (St. Louis, MO, USA), and the Caspase-3 (active) Human ELISA kit from Invitrogen (Camarillo, CA, USA). 3-(Trihydroxysilyl)propyl methylphosphonate monosodium salt solution was purchased from Santa Cruz Biotechnology, Texas, USA. Methanol, ethanol, and acetic acid were obtained from Fisher Scientific UK (Loughborough, UK). Dimethyl sulfoxide (DMSO) was obtained from Tedia (Fairfield, OH, USA). 1-(3-dimethylaminopropyl)-3-ethylcarbodiimide hydrochloride (EDC), N-hydroxysuccinimide (NHS), and chitosan (100,000-300,000 Da) were obtained from Acros Organics (Geel, Belgium). Phosphate-buffered saline (PBS), Dulbecco's modified Eagle medium (DMEM), Roswell Park Memorial Institute medium (RPMI 1640), and fetal bovine serum (FBS) were obtained from Gibco/Life Technologies (Thermo Fisher Scientific, Langenselbold, Germany). Insulin (Novo Nordisk, Bagsvaerd, Denmark) and trypsin versene (Vacsera, Giza, Egypt) were also used. The well plates were obtained from Greiner Bio-One GmbH (Frickenhausen, Germany). The Annexin V-FITC Apoptosis Detection Kit was from BioVision (Mountain View, CA, USA), the flow cytometry kit for cell cycle analysis (ab139418) from Abcam ${ }^{\circledR}$ (Cambridge, UK), Script One-Step RT-PCR Kit with SYBR $^{\circledR}$ Green from BIO-RAD (Hercules, CA, USA), Human Angiopoietin 2 ELISA Kit and Human Programmed Cell Death Protein 1 ELISA Kit from Bioassay Technology Laboratory Systems (Shanghai, China), Human CD44 ELISA kit from Gen-Probe Diaclone SAS (Besançon, France), and the miRNeasy extraction kit from Qiagen (Valencia, CA, USA). Enzyme-linked immunosorbent assays (ELISAs) used a kit for tubulin $\beta$ (TUBb; SEB870Hu, Cloud-Clone Corp., Houston, TX, USA) and human B-RAF/B-Raf sandwich ELISA (LifeSpan BioSciences, Seattle, WA, USA). TMRE Mitochondrial Membrane Potential Assay Kit (Cymans Chemical, Ann Arbor, MI, USA). Cytochrome c Human ELISA Kit (abcam, Austria). Ultrapure water (18.2 M $\Omega$; Milli- $Q^{\circledR}$ system, Millipore, Darmstadt, Germany) was used in all prepared solutions. All other reagents were of analytical grade.

\subsection{Methods}

\subsubsection{Synthesis and Modification of Mesoporous Silica Nanoparticles}

We prepared MSNs of KCC-1 type nanospheres with a 3D fibrous dendritic structure using the detailed synthesis methods according to Polshettiwar et al. [30] and AbouAitah et al. [26]. For further surface modification through the post-synthesis route, to graft phosphonate groups, the MSNs were dried at $50{ }^{\circ} \mathrm{C}$ for $5 \mathrm{~h}$ to remove the physically adsorbed water. Next, $1 \mathrm{~g}$ of dried MSNs was suspended in $100 \mathrm{~mL}$ of ultra-pure water with the aid of sonication (Elma GmbH, Singen, Germany) for $30 \mathrm{~min}$, and then $1.5 \mathrm{~mL}$ of 3-(trihydroxysilyl)propyl methylphosphonate monosodium salt was added drop-wise over with stirring. The mixture solution was left at room temperature under reflux conditions for $24 \mathrm{~h}$. The material was collected by centrifugation (Cooling Sigma 16K, Laborzentrifugen GmbH, Osterode am Harz, Germany) at 10,000 rpm for $10 \mathrm{~min}$, and then washed three times with methanol. Finally, the material was dried in an oven at $50{ }^{\circ} \mathrm{C}$ for $6 \mathrm{~h}$ to obtain MSNsP.

\subsubsection{Colchicine Loading}

To load COL into MSNsP, we followed our previous method with some modification [38]: $100 \mathrm{mg}$ COL was dissolved in $10 \mathrm{~mL}$ deionized water (pH 7), and then $300 \mathrm{mg}$ of MSNsP was added and stirred (DAIHAN Scientific, Seoul, Korea) for $24 \mathrm{~h}$ at room temperature. The solution was centrifuged (Cooling Sigma 16K, Laborzentrifugen GmbH, Osterode am Harz, Germany) for 10 min and washed with deionized water once. Finally, the collected material was heated in an oven at $50{ }^{\circ} \mathrm{C}$ for $12 \mathrm{~h}$ and labeled as MSNsPCOL. 


\subsubsection{Coating and Conjugation with Chitosan-Glycine and Folic Acid}

Coating with chitosan-glycine and conjugating with folic acid was achieved via the following steps. First, the chitosan-glycine was prepared based on a coacervate and EDC/NHS coupling reaction [27] by dissolving $250 \mathrm{mg}$ of chitosan in $20 \mathrm{~mL}(2 \%)$ acetic acid and stirred for $2 \mathrm{~h}$ at $60^{\circ} \mathrm{C}$ (solution A). In another beaker, $100 \mathrm{mg}$ of glycine was dissolved in 10 deionized water, followed by the addition of $60 \mathrm{mg}$ EDC and $50 \mathrm{mg}$ NHS and stirring for $2 \mathrm{~h}$ at room temperature (solution B). Solution B was introduced to solution A drop-wise and left to stir for $4 \mathrm{~h}$ at $50^{\circ} \mathrm{C}$. Hereafter, the mixture solution is referred to as the CG complex solution. Second, the activation of folic acid was carried out by dissolving $85 \mathrm{mg}$ of folic acid, $70 \mathrm{mg}$ of EDC, and $50 \mathrm{mg}$ of NHS in $20 \mathrm{~mL}$ DMSO, stirring the mixture for $20 \mathrm{~h}$ at room temperature. Third, the activated folic acid solution was added drop-wise into the CG complex solution and stirred for $4 \mathrm{~h}$ at $50^{\circ} \mathrm{C}$ to obtain CG-FA complex solution. The solution was kept at $-20^{\circ} \mathrm{C}$ until further use. Fourth, COL-loaded nanoparticles were coated with chitosan-glycine and conjugated to folic acid by dispersing $600 \mathrm{mg}$ of MSNsPCOL into $15 \mathrm{~mL}$ of CG-FA complex solution and stirring at room temperature for $24 \mathrm{~h}$. The MSNsPCOL-CG-FA product was collected by centrifugation and washed with ethanol and ultra-pure water, then dried in an oven at $50^{\circ} \mathrm{C}$ for $12 \mathrm{~h}$.

\subsubsection{Characterization Techniques}

The following techniques were used to characterize the obtained materials: Field emission scanning electron microscopy (FE-SEM; Ultra Plus, Zeiss, Germany) equipped with QUANTAX EDS (Bruker); scanning transmission electron microscopy (STEM; FEI TECNAI G2 F20 S-TWIN, Thermo Fisher Scientific, Waltham, MA, USA); powder X-ray diffraction (XRD; X'PertPRO System, PANalytical) using $\mathrm{CuK} \alpha$ radiation in the $2 \theta$ range of 10-100; and Brunauer, Emmett, and Teller (BET) specific surface area analysis using a Gemini 2360 instrument (Micromeritics) according to ISO 9277:2010. Before the density and SSA measurements were carried out, the powders were dried at $150{ }^{\circ} \mathrm{C}$ (without drug) or $50{ }^{\circ} \mathrm{C}$ (with drug and polymer) for $24 \mathrm{~h}$ under a constant flow of helium (FlowPrep 060 desorption station by Micromeritics). Fourier transformed infrared (FTIR) spectroscopy (Bruker Optics Tensor 27, Bruker Corporation, Billerica, MA, USA) was performed with attenuated total reflectance (ATR, model Platinum ATR-Einheit A 255). Simultaneous thermal analysis (STA)-coupled differential scanning calorimetry (DSC) (STA-DSC) analysis was performed using the STA 499 F1Jupiter (NETZSCH-Feinmahltechnik GmbH, Germany). Samples weighing 10-20 mg were inserted into the alumina pan of the STA unit, and before measurements, helium was flowed through the STA furnace chamber for $30 \mathrm{~min}$. The experimental parameters were programmed to reach $850{ }^{\circ} \mathrm{C}$ with a heating rate of $10^{\circ} \mathrm{C} / \mathrm{min}$ under a helium/air mixture. Zeta potential measurements using a Malvern ZetaSizer (NanoZS, UK) were performed based on the water suspension of nanoparticles at $24{ }^{\circ} \mathrm{C}$. Water suspensions were used for nanoparticle tracking analysis (NTA) using NanoSight NS500 instrument (Malvern Instruments Ltd., Malvern, UK) and data analyzed by NanoSight software (Malvern Instruments Ltd., Malvern, UK).

\subsubsection{In Vitro Cytotoxicity Assessment}

For the estimation of in vitro cytotoxic potency, the 3-4,5-dimethylthiazol-Z-yl-2,5-diphenyltetrazolium bromide (MTT) assay was conducted according to Mosmann [96]. Human prostate adenocarcinoma PC3 cells (ATCC ${ }^{\circledR}$ CRL-1435 TM), human colon colorectal carcinoma HCT116 cells (ATCC ${ }^{\circledR}$ CCL-247 ${ }^{\mathrm{TM}}$ ), human hepatic carcinoma HepG2 cells (ATCC ${ }^{\circledR}$ HB-8065 ${ }^{\mathrm{TM}}$ ), and human fibroblast BJ1 cells (ATCC ${ }^{\circledR}$ CRL-2522 ${ }^{\mathrm{TM}}$ ) were grown in RPMI supplemented with $10 \%$ fetal bovine serum (Cologne, Germany) and 1\% penicillin-streptomycin solution (penicillin 10,000 IU/mL; streptomycin 10,000 $\mu \mathrm{g} / \mathrm{mL}$. The cell lines were cultured at $37^{\circ} \mathrm{C}$ in $95 \%$ humidity and $5 \% \mathrm{CO}_{2}$, and subcultured twice weekly using trypsin versene $0.15 \%$. The cells were seeded in flat-bottom 96 -well plates at a density of 10,000 cells per well for $24 \mathrm{~h}$. The serum enriched medium was used during the bioassay to keep the cells alive through the long duration of the bioassay and to better simulate in vivo conditions. Cells were 
treated with the different samples diluted in medium at 125, 250,500, and $1000 \mu \mathrm{g} / \mathrm{mL}$ (for MSNs and MSNsP) to test the biocompatibility of nanoparticles. For anticancer activity, cells were treated (as equivalent amount to COL in nanoformulations, the equivalent amount used throughout all studies for investigated nanoformulations) at 25, 50, 100, $200 \mu \mathrm{g} / \mathrm{mL}$ (for MSNsPCOL, MSNsPCOL/CG-FA, $\mathrm{COL}, 5-\mathrm{FU})$. After treatment for 24,48 , or $72 \mathrm{~h}, 10 \mu \mathrm{L}$ of MTT was added, and after $5 \mathrm{~h}$ of incubation the color was measured at $495 \mathrm{~nm}$ against the $690 \mathrm{~nm}$ reference. Finally, the percent cytotoxicity was calculated according to $[1-(\operatorname{av}(\mathrm{S}) /(\operatorname{av}(\mathrm{NC}))] \times 100$, where $\operatorname{av}(\mathrm{NC})$ is the average absorbance of the three negative control wells measured at $495 \mathrm{~nm}$ (reference $690 \mathrm{~nm}$ ) and av(S) is the average absorbance of the three sample wells measured at $495 \mathrm{~nm}$ (reference $690 \mathrm{~nm}$ ). IC50 and IC90 values were calculated using Probit analysis and SPSS for Windows statistical analysis software package, version 9 (1989, SPSS Inc., Chicago, IL, USA).

\subsubsection{Apoptosis Detection and Cell Cycle Analysis with Flow Cytometry}

To analyze apoptosis and the cell cycle, we followed manufacture protocols and our pervious study [27]; HCT116 cells were seeded on a six-well plate at a density of $2 \times 10^{5}$ cells/per well in RPMI 1640 supplemented with $10 \%$ FBS, $1 \%$ penicillin/streptomycin and incubated at $37^{\circ} \mathrm{C}$ in a $5 \%$ $\mathrm{CO}_{2}$ atmosphere. After $24 \mathrm{~h}$, the medium was replaced with fresh, treated with different samples at $40 \mu \mathrm{g} / \mathrm{mL}(100 \mu \mathrm{L})$, and incubated for $24 \mathrm{~h}$ or $72 \mathrm{~h}$. Control cells received no treatments. For cell cycle analysis, cells were trypsinized, washed with cold PBS, and fixed with $70 \%$ ethanol. The fixed cells were rinsed with PBS, and then labeled with propidium iodide (PI) following the manufacturer's instructions (Abcam ${ }^{\circledR}$, Cambridge, UK). Finally, cells were analyzed by flow cytometry (FACSCalibur, Becton Dickinson, NJ, USA). Cell cycle analysis was performed with an FL2-A histogram of single cells. The Annexin V-FITC Apoptosis Detection Kit (BioVision, CA, USA) was used to detect apoptosis according to the manufacturer's instructions. After treating the cells as mentioned, the cells were trypsinized, fixed in $70 \%$ ethanol, washed with cold PBS, and suspended in binding buffer $(500 \mu \mathrm{L})$. Next, $5 \mu \mathrm{L}$ of Annexin V-FITC and $5 \mu \mathrm{L}$ of PI were added and incubated for $10 \mathrm{~min}$ in the dark, and then immediately analyzed by flow cytometry (FACSCalibur, Becton Dickinson, NJ, USA).

\subsubsection{Caspase-3 Activity Assay}

The caspase- 3 activity was determined according to the manufacturer's instructions using the human active caspase-3 content assay kit. HCT116 cells were cultured on 96-well plates (1.2-1.8 $\times 10,000$ cells/well) in $100 \mu \mathrm{L}$ of RPMI 1640 containing $10 \% \mathrm{FBS}, 1 \%$ penicillin/streptomycin at $37^{\circ} \mathrm{C}$. The cells were treated at 10 and $500 \mu \mathrm{g} / \mathrm{mL}$ (for MSNs and MSNsP) or 10 and $60 \mu \mathrm{g} / \mathrm{mL}$ (for MSNsPCOL, MSNsPCOL/CG-FA, COL, 5-FU) with $100 \mu \mathrm{L}$ sample volume per well and incubated for $72 \mathrm{~h}$ prior to the assay. The procedures are reported in detail in our previous study [27]. The absorbance was measured at $450 \mathrm{~nm}$ using the Robonik P2000 ELISA reader. The assay was performed in triplicate, and data are expressed as mean $\pm \mathrm{SD}$.

\subsubsection{Tubulin Assay}

To assess tubulin polymerization, the ELISA kit for TUBb (SEB870Hu, Cloud-Clone Corp., Houston, TX, USA) was used following the manufacturer's instructions. HCT116 cells were seeded in 96-well plates at a cell density of 1.2-1.8 × 10,000 cells/well in $100 \mu \mathrm{L}$ growth medium (DMEM); $100 \mu \mathrm{L}$ of each sample was added per well. MSNs and MSNsP were tested at 125, 250, 500, and $1000 \mu \mathrm{g} / \mathrm{mL}$, whereas MSNsPCOL, MSNsPCOL/CG-FA, and COL were used at $0.4,2,10$, and $50 \mu \mathrm{g} / \mathrm{mL}$. After $48 \mathrm{~h}$ of incubation, the solution was removed, cells were detached by trypsinization, washed with cold PBS buffer, suspended in PBS, and followed by three freeze/thaw cycles to lyse the cells. Cell lysates were centrifuged in a cooling centrifuge for $10 \mathrm{~min}$, which permits the removal of cellular debris to detect $\beta$-tubulin in the supernatant. The assay was performed as instructed in the kit. Finally, ELISA reader ROBONIK P2000 (Robonik India PVT LTD, Thane, India) was used to measure the color at $450 \mathrm{~nm}$ in triplicate. Data were calculated as percent inhibition. 


\subsubsection{Expression of Bax and Bcl-2}

Cell Culture Treatment and RNA Extraction

HCT116 cells were cultured at a density at $1 \times 10^{6}$ and incubated for $48 \mathrm{~h}$ at 10 and $500 \mu \mathrm{L}$ (for MSNs and MSNsP) or 10 and $60 \mu \mathrm{g} / \mathrm{mL}$ (for MSNsPCOL, MSNsPCOL/CG-FA, COL, and 5-FU). Cells were then collected for RNA extraction using the RNeasy extraction kit according to the manufacturer's protocol (Qiagen, Hilden, Germany). Cells were disrupted in buffer RLT, homogenized, and disrupted before adding ethanol to the lysates to create conditions that subsequently promoted the selective binding of RNA to the RNeasy membrane. A total of $100 \mu$ of sample lysate was added to a RNeasy Mini spin column, with total RNA binding to the membrane. High-quality RNA was eluted using RNase-free water. Centrifugation in a micro-centrifuge was used during all steps (binding, washing, elution).

\section{Quantitative Determination by RT-PCR}

Bax and Bcl-2 expression was investigated by real-time polymerase chain reaction (RT-PCR) using the BIORAD iScript ${ }^{\mathrm{TM}}$ One-Step RT-PCR Kit with SYBR ${ }^{\circledR}$ Green (Bio-Rad, Hercules, CA) according to the manufacturer's instructions and as described by Labib et al. [97]. The RT-PCR reactions were performed using the following primers for the $\mathrm{BAX}, \mathrm{BCL}-2$, and $\beta$-actin genes: Bax F, 5'-GTTTCA TCC AGG ATC GAG CAG-3'; Bax R, 5'-CATCTT CTT CCA GAT GGT GA-3'; Bcl-2 F, 5'-CCTGTG GAT GAC TGA GTA CC-3'; Bcl-2 R, 5'-GAGACA GCC AGG AGA AAT CA-3'; $\beta$-actin $\mathrm{F}$, 5'-GTGACATCCACACCCAGAGG-3'; and $\beta$-actin R, 5' -ACAGGATGTCAAAACTGCCC-3' . The reaction and amplifications protocol done according to Labib et al. [97]. A reaction mix $(50 \mu \mathrm{L})$ was used, prepared as following: 2X Sybr Green RT-PCR Master $(25 \mu \mathrm{l})$, forward primer-10 $\mu \mathrm{M}(1.510 \mu \mathrm{L})$, Reverse primer-10 $\mu \mathrm{M}(1.5 \mu \mathrm{L})$, nuclease-free $\mathrm{H} 2 \mathrm{O}(11 \mu \mathrm{l})$, RNA template (1 pg to 100 ng total RNA) $(10 \mu \mathrm{L})$, and iScript Reverse Transcriptase for One-Step RT-PCR $(1 \mu \mathrm{L})$. The amplification protocol was performed as follows: cDNA synthesis: $50{ }^{\circ} \mathrm{C}(10 \mathrm{~min})$, iScript Reverse transcriptase inactivation (95 $\left.{ }^{\circ} \mathrm{C}, 5 \mathrm{~min}\right)$, PCR cycling and detection $\left(40\right.$ cycle) $\left(95^{\circ} \mathrm{C}, 10 \mathrm{~s}\right)$, data collection step $\left(60{ }^{\circ} \mathrm{C}, 30 \mathrm{~s}\right)$, melt curve analysis $\left(95^{\circ} \mathrm{C}, 1 \mathrm{~min}, 55^{\circ} \mathrm{C}(1 \mathrm{~min})\right.$ and $55^{\circ} \mathrm{C}(10 \mathrm{~s})\left(80 \mathrm{cycles}\right.$, increased $0.5^{\circ} \mathrm{C}$ for each cycle). The reactions were performed in triplicate on a Rotor-Gene 3000 RT-PCR system. The data were analyzed by Rotor-Gene Series Software 1.7 (Build 87).

\subsubsection{BRAF Assay}

The BRAF ELISA kit was used with cell lysates according to the manufacturer's protocol (LifeSpan BioSciences "LSBio", Seattle, WA, USA). HCT116 cells were cultured at density of $1 \times 10^{6}$ and incubated for $48 \mathrm{~h}$ at $125,250,500$, and $1000 \mu \mathrm{l}$ (for MSNs and MSNsP) or $0.4,2,10$, and $50 \mu \mathrm{g} / \mathrm{mL}$ (for MSNsPCOL, MSNsPCOL/CG-FA, COL, and 5-FU). The cells were then collected and pelleted by centrifugation to remove the supernatant before washing three times with PBS. Next, the cells were resuspended in PBS, lysed, and centrifuged at $1500 \times g$ for $10 \mathrm{~min}$ with cooling centrifugation to remove cellular debris. The supernatant was collected for assay, $100 \mu \mathrm{L}$ added to the plate reader and incubated for $90 \mathrm{~min}$ at $37^{\circ} \mathrm{C}$, and the liquid removed. Subsequently, $100 \mu \mathrm{L}$ of $1 \times$ Biotinylated Detection Antibody was added to each well and incubated for $1 \mathrm{~h}$ at $37^{\circ} \mathrm{C}$, followed by removal of the liquid and washing three times with wash buffer. Next, $100 \mu \mathrm{L}$ of $1 \times$ HRP conjugate working solution was added to each well and incubated for $30 \mathrm{~min}$ at $37^{\circ} \mathrm{C}$, then replaced with $90 \mu \mathrm{L}$ of TMB substrate solution and incubated for $15 \mathrm{~min}$ at $37^{\circ} \mathrm{C}$. Finally, $50 \mu \mathrm{L}$ of stop solution was added and the absorbance measured at $450 \mathrm{~nm}$ using the microplate reader ROBONIK P2000 (Robonik India PVT LTD, Thane, India). Measurements were made in triplicate.

\subsubsection{Cytochrome c Assay}

The cytochrome c was measured using the human cytochrome c ELISA kit in cell lysates according to the manufacturer's protocol (Abcam, Austria). HCT116 cells were cultured at density of 1.2-1.8 $\times$ 10,000 cells/well and incubated for $72 \mathrm{~h}$ at $500 \mu \mathrm{L}$ (for MSNs and MSNsP) or $60 \mu \mathrm{g} / \mathrm{mL}$ (for MSNsPCOL, 
MSNsPCOL/CG-FA, COL, and 5-FU). The cells were then collected and pelleted by centrifugation to remove the supernatant before washing with PBS. Next, several steps were procced as the kit protocol. Finally, absorbance was measured at $450 \mathrm{~nm}$ using the microplate reader (Robonik India PVT LTD, Thane, India). Measurements were made in triplicate.

\subsubsection{Measurement of Mitochondrial Membrane Potential}

The mitochondrial membrane potential was done by means of flow cytometry with cell lysates according to the manufacturer's protocol TMRE mitochondrial potential assay (Cyman chemical, Ann Arbor, MI, USA). HCT116 cells were cultured at density of 1.2-1.8 $\times 10,000$ cells/well and incubated for $72 \mathrm{~h}$ at $500 \mu \mathrm{L}$ (for MSNs and MSNsP) or $60 \mu \mathrm{g} / \mathrm{mL}$ (for MSNsPCOL, MSNsPCOL/CG-FA, COL, and 5-FU) with volume of $100 \mu \mathrm{g} / \mathrm{mL}$. The cells were then collected and pelleted by centrifugation to remove the supernatant before washing with PBS. Next, we resuspended it in $100 \mu \mathrm{L}$ of assay buffer assay, followed by adding $100 \mu \mathrm{L}$ of TMRE buffer, and incubated for $30 \mathrm{~min}$. Then, it was centrifuged, and resuspended in assay buffer, and the data collected by flow cytometry (FACSCalibur, Becton Dickinson, Franklin Lakes, NJ, USA). Finally, measurements were made in triplicate.

\subsubsection{Assays for MALAT-1, mir-205, Ang-2-CD44, and PD-1}

\section{Cell Culture and Treatment}

HCT116 colon cancer cells were obtained from American Type Culture Collection (ATCC ${ }^{\circledR}$ CCL-247), cultured in 96-well plates (cells density 1.2-1.8 × 10,000 cells/well) in RPMI 1640 medium supplemented with $10 \% \mathrm{FBS}, 10 \mu \mathrm{g} / \mathrm{mL}$ of insulin, and $1 \%$ penicillin-streptomycin, and allowed to attach and grow for $24 \mathrm{~h}$. The cell culture was treated with different samples, and control cells were left untreated. To prepare cell culture supernatants, after incubation, cells were harvested after detaching with trypsin and lysates collected by centrifugation. The cells were lysed with cell lysis buffer and centrifuged at $1500 \mathrm{~g}$ for $10 \mathrm{~min}$ at $2-8{ }^{\circ} \mathrm{C}$ to exclude cell debris. The expression levels of angiopoietin-2 (Ang-2), PD-1, CD44, metastasis-associated lung adenocarcinoma transcript 1 (MALAT1, and miR-205 were measured in the prepared cell culture supernatants by RT-PCR or ELISA.

The supernatant was used to measure Ang- 2 and PD-1 by ELISA using an ELISA plate reader (Model stat fax 2100, Awareness, Ramsey, MN, USA) according to the manufacturer's instructions. For quantitative detection of total soluble human CD44, normal and variant isoforms were measured by ELISA. For measurement of long non-coding RNAs (lncRNAs) for MALAT1 and mir-205, cells were collected, and RNA extracted using the miRNeasy extraction kit. Total RNA including non-coding RNAs was extracted from supernatants using the miRNeasy extraction kit (Qiagen, Valencia CA, USA) and QIAzollysis reagent according to the manufacturer's instructions. The concentration of RNA was determined using NanoDrop2000, which is very accurate for measuring even the smallest quantities of RNA (NanoDrop2000, Thermo Scientific, Wilmington, NC, USA). Reverse transcription was carried out on extracted RNA in a final volume of $20 \mu \mathrm{L}$ using the RT2 First Strand kit (Qiagen) according to the manufacturer's instructions. The expression levels of the studied lncRNAs were evaluated using GAPDH, which is widely used as an internal control for serum lncRNAs in numerous studies [98,99] according to the manufacturer's protocol. The MALAT1 Ref Seq no. was NR 002819.2. The primer sequences for GAPDH were 5'-CCCTTCATTGACCTCAACTA-3' (forward) and 5'-TGGAAGATGGTGAT GGGATT-3' (reverse). RT-PCR was done in a $20 \mathrm{Ml}$ reaction mixture using the Rotor gene Q System (ROTOR-Gene Q, SN R1211164, Qiagen, Hilden, Germany) with the following conditions: $95^{\circ} \mathrm{C}$ for $10 \mathrm{~min}$, followed by 45 cycles at $9{ }^{\circ} \mathrm{C}$ for $15 \mathrm{~s}$ and $60{ }^{\circ} \mathrm{C}$ for $60 \mathrm{~s}$. The cycle threshold $(\mathrm{Ct})$ method was used to quantify target genes relative to their endogenous control. The $\Delta \mathrm{Ct}$ of microRNAs was calculated by subtracting the $\mathrm{C} t$ values of SNORD 68 from miR-205. The $\Delta \mathrm{Ct}$ of lncRNAs was calculated by subtracting the $\mathrm{Ct}$ value of GAPDH from that of MALAT1. The fold change in miR-205 and MALAT1 expression levels were calculated using the equation $2^{-\Delta \Delta C t}$. Gene expression 
was calculated relative to the internal control $(2-\mathrm{Ct})$. The fold change was calculated using $2-\mathrm{Ct}$ for relative quantitation [100].

\subsection{Statistical Analysis}

Data for biological evaluations are expressed as mean \pm SD. Significance differences were calculated using the Student t-test, Mann Whitney U test, and analysis of variance (ANOVA) analysis at $p<0.05$. All statistical calculations were performed in triplicate using computer program IBM SPSS (Statistical Package for the Social Science; IBM Corp, Armonk, NY, USA) release 22 for Microsoft Windows.

\section{Conclusions}

We successfully designed a novel DDS for COL prodrug that efficiently targets cancer cells. The DDS was fabricated by loading COL into spherical mesoporous silica nanoparticles and their subsequent modification with phosphonate groups. They were subsequently coated with chitosan-glycine complex conjugated to folic acid, which acted as a targeting ligand for cancers. Full inhibition of HCT116 colon cancer cells was observed. A weaker effect was observed in HepG2 liver and PC3 prostate cancer cells. The most important characteristic of the DDS was its negligible cytotoxicity in normal cells. We observed, after $72 \mathrm{~h}$ of incubation with MSNsPCOL/CG-FA, low inhibition in normal BJ1 cells (4\%) compared to free COL ( $60 \%)$. Apoptosis (intrinsic) was found to be the main mechanism of action occurring as a consequence of the strong antimitotic effects. MSNsPCOL/CG-FA more strongly inhibited tubulin than free COL. It also increased the cell cycle at G2/M, caspase-3 activation, and Bax expression compared to COL. On the other hand, MSNsPCOL/CG-FA inhibited anti-apoptotic proteins (Bcl-2, BRAF, and CD44) more strongly than clinically used COL and 5-FU anticancer drugs. New effects of the DDS on genetic regulation and cancer related immuno-effects were found. MSNsPCOL/CG-FA significantly inhibited MALAT1, mir-205 expression, Ang-2 protein, and PD-1 compared to COL and 5-FU. We expect that the tailored DDS for COL has the potential to become a nanomedical platform for cancer treatment.

Supplementary Materials: The following are available online at http://www.mdpi.com/2072-6694/12/1/144/s1, Figure S1: Energy-dispersive X-ray spectroscopy analysis for elemental content (A), and particle size analysis by NTA in aqueous solution (B), Figure S2: Cell cycle analysis in HCT116 colon cancer cells: after $25 \mathrm{~h}$ (A), and after $72 \mathrm{~h}(\mathbf{B})$, Figure S3: Apoptosis analysis by flow cytometry measurements without and with treatments as a function of incubation time in HCT116 cells, Table S1: IC50 of MSNs before and after modification, COL loading, Coating, and folic acid conjugation after $24 \mathrm{~h}, 48 \mathrm{~h}$, and $72 \mathrm{~h}$ incubation with cell lines.

Author Contributions: Conceptualization, K.A.; funding acquisition, K.A. and W.L.; investigation, K.A., H.A.H., A.S.-S., L.G., O.G.S., J.W., A.O., J.S.-K., and S.G.; methodology, K.A., H.A.H., and O.G.S.; resources, K.A., H.A.H., O.G.S., and W.L.; supervision, K.A. and W.L.; writing-original draft, K.A.; writing-review and editing, K.A. and W.L. All authors have read and agreed to the published version of the manuscript.

Funding: The authors would like to thank the National Research Centre (NRC, Egypt) for supporting this work. Many thanks to the National Center for Research and Development, Poland (STRATEGMED3/306888/3/NCBR/2017, project iTE, Poland). This research was carried out using equipment funded by the CePT project, reference: POIG.02.02.00-14-024/08, financed by the European Regional Development Fund within the Operational Programme "Innovative Economy" for 2007-2013.

Acknowledgments: K.A. would like to thank Adam Presz from the Laboratory of Nanostructures, Institute of High Pressure Physics, Polish Academy of Sciences, for the FE-SEM images. The authors would like to thank Essam R. Ahmed, head of the confirmatory diagnostic unit, VACSERA, Dokki, Egypt for his efforts in several molecular assays performed there.

Conflicts of Interest: The authors declare no conflict of interest.

\section{References}

1. Kaplan, M.M.; Alling, D.W.; Zimmerman, H.J.; Wolfe, H.J.; Sepersky, R.A.; Hirsch, G.S.; Elta, G.H.; Glick, K.A.; Eagen, K.A. A prospective trial of colchicine for primary biliary cirrhosis. N. Engl. J. Med. 1986, 315, 1448-1454. [CrossRef] 
2. Cohen, A.S.; Rubinow, A.; Anderson, J.J.; Skinner, M.; Mason, J.H.; Libbey, C.; Kayne, H. Survival of patients with primary (AL) amyloidosis: Colchicine-treated cases from 1976 to 1983 compared with cases seen in previous years (1961 to 1973). Am. J. Med. 1987, 82, 1182-1190. [CrossRef]

3. Gigax, J.H.; Robison, J.R. The Successful Treatment of Intraurethral Condyloma Acuminata with Colchicine. J. Urol. 1971, 105, 809-811. [CrossRef]

4. Sampedro-Núñez, M.; Serrano-Somavilla, A.; Adrados, M.; Cameselle-Teijeiro, J.M.; Blanco-Carrera, C.; Cabezas-Agricola, J.M.; Martínez-Hernández, R.; Martín-Pérez, E.; Muñoz de Nova, J.L.; Díaz, J.Á.; et al. Analysis of expression of the PD-1/PD-L1 immune checkpoint system and its prognostic impact in gastroenteropancreatic neuroendocrine tumors. Sci. Rep. 2018, 8, 17812. [CrossRef] [PubMed]

5. Bhattacharyya, B.; Panda, D.; Gupta, S.; Banerjee, M. Anti-mitotic activity of colchicine and the structural basis for its interaction with tubulin. Med. Res. Rev. 2008, 28, 155-183. [CrossRef] [PubMed]

6. Huang, Z.; Xu, Y.; Peng, W. Colchicine induces apoptosis in HT29 human colon cancer cells via the AKT and c-Jun N-terminal kinase signaling pathways. Mol. Med. Rep. 2015, 12, 5939-5944. [CrossRef]

7. Zhang, L.; Yang, Z.; Granieri, L.; Pasculescu, A.; Datti, A.; Asa, S.L.; Xu, Z.; Ezzat, S. High-throughput drug library screening identifies colchicine as a thyroid cancer inhibitor. Oncotarget 2016, 7, 19948-19959. [CrossRef]

8. Cho, J.H.; Joo, Y.H.; Shin, E.Y.; Park, E.J.; Kim, M.S. Anticancer Effects of Colchicine on Hypopharyngeal Cancer. Anticancer Res. 2017, 37, 6269-6280. [CrossRef]

9. Lin, Z.Y.; Kuo, C.H.; Wu, D.C.; Chuang, W.L. Anticancer effects of clinically acceptable colchicine concentrations on human gastric cancer cell lines. Kaohsiung J. Med. Sci. 2016, 32, 68-73. [CrossRef]

10. Kumar, A.; Sharma, P.R.; Mondhe, D.M. Potential anticancer role of colchicine-based derivatives: An overview. Anti Cancer Drugs 2017, 28, 250-262. [CrossRef]

11. Kumar, A.; Singh, B.; Sharma, P.R.; Bharate, S.B.; Saxena, A.K.; Mondhe, D.M. A novel microtubule depolymerizing colchicine analogue triggers apoptosis and autophagy in HCT-116 colon cancer cells. Cell Biochem. Funct. 2016, 34, 69-81. [CrossRef] [PubMed]

12. Choi, A.R.; Kim, J.H.; Cheon, J.H.; Kim, H.S.; Yoon, S. Attenuation of Colchicine Toxicity in Drug-resistant Cancer Cells by Co-treatment with Anti-malarial Drugs. Anticancer Res. 2016, 36, 5859-5866. [CrossRef] [PubMed]

13. Gupta, R.S.; Dudani, A.K. Mechanism of action of antimitotic drugs: A new hypothesis based on the role of cellular calcium. Med. Hypotheses 1989, 28, 57-69. [CrossRef]

14. Gascoigne, K.E.; Taylor, S.S. How do anti-mitotic drugs kill cancer cells? J. Cell Sci. 2009, 122, $2579-2585$. [CrossRef] [PubMed]

15. Castedo, M.; Perfettini, J.L.; Roumier, T.; Andreau, K.; Medema, R.; Kroemer, G. Cell death by mitotic catastrophe: A molecular definition. Oncogene 2004, 23, 2825-2837. [CrossRef]

16. Qi, C.; Wang, X.; Shen, Z.; Chen, S.; Yu, H.; Williams, N.; Wang, G. Anti-mitotic chemotherapeutics promote apoptosis through TL1A-activated death receptor 3 in cancer cells. Cell Res. 2018, 28, 544-555. [CrossRef]

17. Fong, A.; Durkin, A.; Lee, H. The Potential of Combining Tubulin-Targeting Anticancer Therapeutics and Immune Therapy. Int. J. Mol. Sci. 2019, 20, 586. [CrossRef]

18. Fourcade, J.; Sun, Z.; Benallaoua, M.; Guillaume, P.; Luescher, I.F.; Sander, C.; Kirkwood, J.M.; Kuchroo, V.; Zarour, H.M. Upregulation of Tim-3 and PD-1 expression is associated with tumor antigen-specific CD8+ T cell dysfunction in melanoma patients. J. Exp. Med. 2010, 207, 2175-2186. [CrossRef]

19. Silva, R.; Gullo, I.; Carneiro, F. The PD-1:PD-L1 immune inhibitory checkpoint in Helicobacter pylori infection and gastric cancer: A comprehensive review and future perspectives. Porto Biomed. J. 2016, 1, 4-11. [CrossRef]

20. Yao, H.; Wang, H.; Li, C.; Fang, J.-Y.; Xu, J. Cancer Cell-Intrinsic PD-1 and Implications in Combinatorial Immunotherapy. Front. Immunol. 2018, 9, 1774. [CrossRef]

21. Berntsson, J.; Eberhard, J.; Nodin, B.; Leandersson, K.; Larsson, A.H.; Jirström, K. Expression of programmed cell death protein 1 (PD-1) and its ligand PD-L1 in colorectal cancer: Relationship with sidedness and prognosis. Oncoimmunology 2018, 7, e1465165. [CrossRef] [PubMed]

22. Syn, N.L.; Teng, M.W.L.; Mok, T.S.K.; Soo, R.A. De-novo and acquired resistance to immune checkpoint targeting. Lancet Oncol. 2017, 18, e731-e741. [CrossRef] 
23. Franchini, D.-M.; Lanvin, O.; Tosolini, M.; Patras de Campaigno, E.; Cammas, A.; Péricart, S.; Scarlata, C.-M.; Lebras, M.; Rossi, C.; Ligat, L.; et al. Microtubule-Driven Stress Granule Dynamics Regulate Inhibitory Immune Checkpoint Expression in T Cells. Cell Rep. 2019, 26, 94-107. [CrossRef] [PubMed]

24. Ades, S. Adjuvant chemotherapy for colon cancer in the elderly: Moving from evidence to practice. Oncology 2009, 23, 162-167. [PubMed]

25. Banerjee, A.; Pathak, S.; Subramanium, V.D.; Dharanivasan, G.; Murugesan, R.; Verma, R.S. Strategies for targeted drug delivery in treatment of colon cancer: Current trends and future perspectives. Drug Discov. Today 2017, 22, 1224-1232. [CrossRef] [PubMed]

26. AbouAitah, K.; Swiderska-Sroda, A.; Farghali, A.A.; Wojnarowicz, J.; Stefanek, A.; Gierlotka, S.; Opalinska, A.; Allayeh, A.K.; Ciach, T.; Lojkowski, W. Folic acid-conjugated mesoporous silica particles as nanocarriers of natural prodrugs for cancer targeting and antioxidant action. Oncotarget 2018, 9, 26466-26490. [CrossRef] [PubMed]

27. Shahein, S.A.; Aboul-Enein, A.M.; Higazy, I.M.; Abou-Elella, F.; Lojkowski, W.; Ahmed, E.R.; Mousa, S.A.; AbouAitah, K. Targeted anticancer potential against glioma cells of thymoquinone delivered by mesoporous silica core-shell nanoformulations with pH-dependent release. Int. J. Nanomed. 2019, 14, 5503-5526. [CrossRef]

28. Cauda, V.; Engelke, H.; Sauer, A.; Arcizet, D.; Brauchle, C.; Radler, J.; Bein, T. Colchicine-loaded lipid bilayer-coated $50 \mathrm{~nm}$ mesoporous nanoparticles efficiently induce microtubule depolymerization upon cell uptake. Nano Lett. 2010, 10, 2484-2492. [CrossRef]

29. Muvaffak, A.; Gurhan, I.; Hasirci, N. Prolonged cytotoxic effect of colchicine released from biodegradable microspheres. J. Biomed. Mater. Res. Part B Appl. Biomater. 2004, 71, 295-304. [CrossRef]

30. Polshettiwar, V.; Cha, D.; Zhang, X.; Basset, J.M. High-surface-area silica nanospheres (KCC-1) with a fibrous morphology. Angew. Chem. Int. Ed. Engl. 2010, 49, 9652-9656. [CrossRef]

31. Chang, B.; Chen, D.; Wang, Y.; Chen, Y.; Jiao, Y.; Sha, X.; Yang, W. Bioresponsive Controlled Drug Release Based on Mesoporous Silica Nanoparticles Coated with Reductively Sheddable Polymer Shell. Chem. Mater. 2013, 25, 574-585. [CrossRef]

32. Castillo, R.R.; Lozano, D.; González, B.; Manzano, M.; Izquierdo-Barba, I.; Vallet-Regí, M. Advances in mesoporous silica nanoparticles for targeted stimuli-responsive drug delivery: An update. Expert Opin. Drug Deliv. 2019, 16, 415-439. [CrossRef] [PubMed]

33. Lukey, M.J.; Katt, W.P.; Cerione, R.A. Targeting amino acid metabolism for cancer therapy. Drug Discov. Today 2017, 22, 796-804. [CrossRef] [PubMed]

34. Fernández, M.; Javaid, F.; Chudasama, V. Advances in targeting the folate receptor in the treatment/imaging of cancers. Chem. Sci. 2018, 9, 790-810. [CrossRef] [PubMed]

35. Sabharanjak, S.; Mayor, S. Folate receptor endocytosis and trafficking. Adv. Drug Deliv. Rev. 2004, 56, 1099-1109. [CrossRef]

36. Zwicke, G.L.; Ali Mansoori, G.; Jeffery, C.J. Utilizing the folate receptor for active targeting of cancer nanotherapeutics. Nano Rev. 2012, 3, 18496. [CrossRef]

37. AbouAitah, K.; Farghali, A.; Swiderska-Sroda, A.; Lojkowski, W.; Razin, A.; Khedr, M.K. Mesoporous silica materials in drug delivery system: $\mathrm{pH} /$ glutathione-responsive release of poorly water-soluble pro-drug quercetin from two and three-dimensional pore-structure nanoparticles. J. Nanomed. Nanotechnol. 2016, 7. [CrossRef]

38. AbouAitah, K.E.; Farghali, A.; Swiderska-Sroda, A.; Lojkowski, W.; Razin, A.; Khedr, M.K. pH-controlled release system for curcumin based on functionalized dendritic mesoporous silica nanoparticles. J. Nanomed. Nanotechnol. 2016, 7. [CrossRef]

39. Menon, N.; Leong, D.T. Cytotoxic Effects of Phosphonate-Functionalized Mesoporous Silica Nanoparticles. ACS Appl. Mater. Interfaces 2016, 8, 2416-2422. [CrossRef]

40. Villanueva, A.; Canete, M.; Roca, A.G.; Calero, M.; Veintemillas-Verdaguer, S.; Serna, C.J.; Morales Mdel, P.; Miranda, R. The influence of surface functionalization on the enhanced internalization of magnetic nanoparticles in cancer cells. Nanotechnology 2009, 20, 115103. [CrossRef]

41. Yue, Z.-G.; Wei, W.; Lv, P.-P.; Yue, H.; Wang, L.-Y.; Su, Z.-G.; Ma, G.-H. Surface Charge Affects Cellular Uptake and Intracellular Trafficking of Chitosan-Based Nanoparticles. Biomacromolecules 2011, 12, 2440-2446. [CrossRef] [PubMed] 
42. Fröhlich, E. The role of surface charge in cellular uptake and cytotoxicity of medical nanoparticles. Int. J. Nanomed. 2012, 7, 5577-5591. [CrossRef] [PubMed]

43. Zhang, S.; Gao, H.; Bao, G. Physical Principles of Nanoparticle Cellular Endocytosis. ACS Nano 2015, 9, 8655-8671. [CrossRef] [PubMed]

44. Xin, Y.; Yin, M.; Zhao, L.; Meng, F.; Luo, L. Recent progress on nanoparticle-based drug delivery systems for cancer therapy. Cancer Biol. Med. 2017, 14, 228-241. [CrossRef] [PubMed]

45. Tran, S.; DeGiovanni, P.-J.; Piel, B.; Rai, P. Cancer nanomedicine: A review of recent success in drug delivery. Clin. Transl. Med. 2017, 6, 44. [CrossRef]

46. Chen, T.; Wu, W.; Xiao, H.; Chen, Y.; Chen, M.; Li, J. Intelligent Drug Delivery System Based on Mesoporous Silica Nanoparticles Coated with an Ultra-pH-Sensitive Gatekeeper and Poly(ethylene glycol). ACS Macro Lett. 2016, 5, 55-58. [CrossRef]

47. Cheung, A.; Bax, H.J.; Josephs, D.H.; Ilieva, K.M.; Pellizzari, G.; Opzoomer, J.; Bloomfield, J.; Fittall, M.; Grigoriadis, A.; Figini, M.; et al. Targeting folate receptor alpha for cancer treatment. Oncotarget 2016, 7, 52553-52574. [CrossRef]

48. Andreu, J.M.; Perez-Ramirez, B.; Gorbunoff, M.J.; Ayala, D.; Timasheff, S.N. Role of the colchicine ring A and its methoxy groups in the binding to tubulin and microtubule inhibition. Biochemistry 1998, 37, 8356-8368. [CrossRef]

49. Jordan, M.A.; Wilson, L. Microtubules as a target for anticancer drugs. Nat. Rev. Cancer 2004, 4, $253-265$. [CrossRef]

50. Lu, Y.; Chen, J.; Xiao, M.; Li, W.; Miller, D.D. An overview of tubulin inhibitors that interact with the colchicine binding site. Pharm. Res. 2012, 29, 2943-2971. [CrossRef]

51. Blajeski, A.L.; Phan, V.A.; Kottke, T.J.; Kaufmann, S.H. G(1) and G(2) cell-cycle arrest following microtubule depolymerization in human breast cancer cells. J. Clin. Investig. 2002, 110, 91-99. [CrossRef] [PubMed]

52. Kulshrestha, A.; Katara, G.K.; Ibrahim, S.A.; Patil, R.; Patil, S.A.; Beaman, K.D. Microtubule inhibitor, SP-6-27 inhibits angiogenesis and induces apoptosis in ovarian cancer cells. Oncotarget 2017, 8, 67017-67028. [CrossRef] [PubMed]

53. Cuddihy, A.R.; O'Connell, M.J. Cell-cycle responses to DNA damage in G2. Int. Rev. Cytol. 2003, 222, 99-140. [PubMed]

54. Johnstone, R.W.; Ruefli, A.A.; Lowe, S.W. Apoptosis: A Link between Cancer Genetics and Chemotherapy. Cell 2002, 108, 153-164. [CrossRef]

55. Hengartner, M.O. The biochemistry of apoptosis. Nature 2000, 407, 770-776. [CrossRef]

56. Kim, S.-K.; Cho, S.-M.; Kim, H.; Seok, H.; Kim, S.-O.; Kwon, T.K.; Chang, J.-S. The colchicine derivative CT20126 shows a novel microtubule-modulating activity with apoptosis. Exp. Mol. Med. 2013, 45, e19. [CrossRef]

57. Lowe, S.W.; Lin, A.W. Apoptosis in cancer. Carcinogenesis 2000, 21, 485-495. [CrossRef]

58. Boonstra, J.; Post, J.A. Molecular events associated with reactive oxygen species and cell cycle progression in mammalian cells. Gene 2004, 337, 1-13. [CrossRef]

59. Nagappan, A.; Lee, W.S.; Yun, J.W.; Lu, J.N.; Chang, S.-H.; Jeong, J.-H.; Kim, G.S.; Jung, J.-M.; Hong, S.C. Tetraarsenic hexoxide induces G2/M arrest, apoptosis, and autophagy via PI3K/Akt suppression and p38 MAPK activation in SW620 human colon cancer cells. PLoS ONE 2017, 12, e0174591. [CrossRef]

60. McIlwain, D.R.; Berger, T.; Mak, T.W. Caspase functions in cell death and disease. Cold Spring Harb. Perspect. Biol. 2013, 5, a008656. [CrossRef]

61. Vaux, D.L.; Cory, S.; Adams, J.M. Bcl-2 gene promotes haemopoietic cell survival and cooperates with c-myc to immortalize pre-B cells. Nature 1988, 335, 440-442. [CrossRef] [PubMed]

62. Scherr, A.-L.; Gdynia, G.; Salou, M.; Radhakrishnan, P.; Duglova, K.; Heller, A.; Keim, S.; Kautz, N.; Jassowicz, A.; Elssner, C.; et al. Bcl- $\mathrm{x}_{\mathrm{L}}$ is an oncogenic driver in colorectal cancer. Cell Death Dis. 2016, 7, e2342. [CrossRef] [PubMed]

63. Rampino, N.; Yamamoto, H.; Ionov, Y.; Li, Y.; Sawai, H.; Reed, J.C.; Perucho, M. Somatic Frameshift Mutations in the BAX Gene in Colon Cancers of the Microsatellite Mutator Phenotype. Science 1997, 275, 967-969. [CrossRef] [PubMed]

64. Vogelstein, B.; Fearon, E.R.; Hamilton, S.R.; Kern, S.E.; Preisinger, A.C.; Leppert, M.; Nakamura, Y.; White, R.; Smits, A.M.; Bos, J.L. Genetic alterations during colorectal-tumor development. N. Engl. J. Med. 1988, 319, 525-532. [CrossRef] 
65. Peyssonnaux, C.; Eychène, A. The Raf/MEK/ERK pathway: New concepts of activation. Biol. Cell 2001, 93, 53-62. [CrossRef]

66. Ikehara, N.; Semba, S.; Sakashita, M.; Aoyama, N.; Kasuga, M.; Yokozaki, H. BRAF mutation associated with dysregulation of apoptosis in human colorectal neoplasms. Int. J. Cancer 2005, 115, 943-950. [CrossRef]

67. Erhardt, P.; Schremser, E.J.; Cooper, G.M. B-Raf inhibits programmed cell death downstream of cytochrome c release from mitochondria by activating the MEK/Erk pathway. Mol. Cell. Biol. 1999, 19, 5308-5315. [CrossRef]

68. Zhang, T.; Chen, W.; Jiang, X.; Liu, L.; Wei, K.; Du, H.; Wang, H.; Li, J. Anticancer effects and underlying mechanism of Colchicine on human gastric cancer cell lines in vitro and in vivo. Biosci. Rep. 2019, 39. [CrossRef]

69. Nagano, O.; Saya, H. Mechanism and biological significance of CD44 cleavage. Cancer Sci. 2004, 95, 930-935. [CrossRef]

70. Chen, C.; Zhao, S.; Karnad, A.; Freeman, J.W. The biology and role of CD44 in cancer progression: Therapeutic implications. J. Hematol. Oncol. 2018, 11, 64. [CrossRef]

71. Park, Y.S.; Huh, J.W.; Lee, J.H.; Kim, H.R. shRNA against CD44 inhibits cell proliferation, invasion and migration, and promotes apoptosis of colon carcinoma cells. Oncol. Rep. 2012, 27, 339-346. [CrossRef] [PubMed]

72. Zhou, J.-Y.; Chen, M.; Ma, L.; Wang, X.; Chen, Y.-G.; Liu, S.-L. Role of CD44(high)/CD133(high) HCT-116 cells in the tumorigenesis of colon cancer. Oncotarget 2016, 7, 7657-7666. [CrossRef] [PubMed]

73. Sahlberg, S.H.; Spiegelberg, D.; Glimelius, B.; Stenerlow, B.; Nestor, M. Evaluation of cancer stem cell markers CD133, CD44, CD24: Association with AKT isoforms and radiation resistance in colon cancer cells. PLoS ONE 2014, 9, e94621. [CrossRef] [PubMed]

74. Schneider, M.; Huber, J.; Hadaschik, B.; Siegers, G.M.; Fiebig, H.H.; Schuler, J. Characterization of colon cancer cells: A functional approach characterizing CD133 as a potential stem cell marker. BMC Cancer 2012, 12, 96. [CrossRef] [PubMed]

75. Lakshman, M.; Subramaniam, V.; Rubenthiran, U.; Jothy, S. CD44 promotes resistance to apoptosis in human colon cancer cells. Exp. Mol. Pathol. 2004, 77, 18-25. [CrossRef]

76. Ponting, C.P.; Oliver, P.L.; Reik, W. Evolution and Functions of Long Noncoding RNAs. Cell 2009, 136, 629-641. [CrossRef]

77. Zhao, M.; Wang, S.; Li, Q.; Ji, Q.; Guo, P.; Liu, X. MALAT1: A long non-coding RNA highly associated with human cancers. Oncol. Lett. 2018, 16, 19-26. [CrossRef]

78. Okugawa, Y.; Toiyama, Y.; Hur, K.; Toden, S.; Saigusa, S.; Tanaka, K.; Inoue, Y.; Mohri, Y.; Kusunoki, M.; Boland, C.R.; et al. Metastasis-associated long non-coding RNA drives gastric cancer development and promotes peritoneal metastasis. Carcinogenesis 2014, 35, 2731-2739. [CrossRef]

79. Wu, X.S.; Wang, X.A.; Wu, W.G.; Hu, Y.P.; Li, M.L.; Ding, Q.; Weng, H.; Shu, Y.J.; Liu, T.Y.; Jiang, L.; et al. MALAT1 promotes the proliferation and metastasis of gallbladder cancer cells by activating the ERK/MAPK pathway. Cancer Biol. Ther. 2014, 15, 806-814. [CrossRef]

80. Gutschner, T.; Hammerle, M.; Eissmann, M.; Hsu, J.; Kim, Y.; Hung, G.; Revenko, A.; Arun, G.; Stentrup, M.; Gross, M.; et al. The noncoding RNA MALAT1 is a critical regulator of the metastasis phenotype of lung cancer cells. Cancer Res. 2013, 73, 1180-1189. [CrossRef]

81. Yang, M.-H.; Hu, Z.-Y.; Xu, C.; Xie, L.-Y.; Wang, X.-Y.; Chen, S.-Y.; Li, Z.-G. MALAT1 promotes colorectal cancer cell proliferation/migration/invasion via PRKA kinase anchor protein 9. Biochim Biophys Acta 2015, 1852, 166-174. [CrossRef]

82. Wu, C.; Zhu, X.; Tao, K.; Liu, W.; Ruan, T.; Wan, W.; Zhang, C.; Zhang, W. MALAT1 promotes the colorectal cancer malignancy by increasing DCP1A expression and miR203 downregulation. Mol. Carcinog. 2018, 57, 1421-1431. [CrossRef]

83. Esquela-Kerscher, A.; Slack, F.J. Oncomirs-MicroRNAs with a role in cancer. Nat. Rev. Cancer 2006, 6, 259-269. [CrossRef]

84. Lee, R.C.; Feinbaum, R.L.; Ambros, V. The C. elegans heterochronic gene lin-4 encodes small RNAs with antisense complementarity to lin-14. Cell 1993, 75, 843-854. [CrossRef]

85. Schetter, A.J.; Okayama, H.; Harris, C.C. The role of microRNAs in colorectal cancer. Cancer J. 2012, 18, 244-252. [CrossRef] 
86. Cekaite, L.; Eide, P.W.; Lind, G.E.; Skotheim, R.I.; Lothe, R.A. MicroRNAs as growth regulators, their function and biomarker status in colorectal cancer. Oncotarget 2016, 7, 6476-6505. [CrossRef]

87. Jing, N.; Yin, L.; Sun, J.; Cao, Z.; Mao, W. Expression levels of miR-205 and miR-506 in colon cancer tissues and their relationships with clinicopathological features. Oncol. Lett. 2018, 16, 4331-4336. [CrossRef]

88. Orang, A.V.; Safaralizadeh, R.; Hosseinpour Feizi, M.A.; Somi, M.H. Diagnostic and prognostic value of miR-205 in colorectal cancer. Asian Pac. J. Cancer Prev. 2014, 15, 4033-4037. [CrossRef]

89. Schmittnaegel, M.; Rigamonti, N.; Kadioglu, E.; Cassara, A.; Wyser Rmili, C.; Kiialainen, A.; Kienast, Y.; Mueller, H.J.; Ooi, C.H.; Laoui, D.; et al. Dual angiopoietin-2 and VEGFA inhibition elicits antitumor immunity that is enhanced by PD-1 checkpoint blockade. Sci. Transl. Med. 2017, 9. [CrossRef]

90. Kim, H.; Ahn, T.S.; Kim, C.-J.; Bae, S.B.; Kim, H.J.; Lee, C.-S.; Kim, T.H.; Im, J.; Lee, S.H.; Son, M.W.; et al. Oncogenic function of angiopoietin-2 in vitro and its modulation of tumor progression in colorectal carcinoma. Oncol. Lett. 2017, 14, 553-560. [CrossRef]

91. Fukumura, D.; Kloepper, J.; Amoozgar, Z.; Duda, D.G.; Jain, R.K. Enhancing cancer immunotherapy using antiangiogenics: Opportunities and challenges. Nat. Rev. Clin. Oncol. 2018, 15, 325-340. [CrossRef]

92. Khalil, D.N.; Smith, E.L.; Brentjens, R.J.; Wolchok, J.D. The future of cancer treatment: Immunomodulation, CARs and combination immunotherapy. Nature reviews. Clin. Oncol. 2016, 13, 273-290. [CrossRef]

93. Webb, E.S.; Liu, P.; Baleeiro, R.; Lemoine, N.R.; Yuan, M.; Wang, Y.-H. Immune checkpoint inhibitors in cancer therapy. J. Biomed. Res. 2018, 32, 317-326. [CrossRef]

94. Ottaviano, M.; De Placido, S.; Ascierto, P.A. Recent success and limitations of immune checkpoint inhibitors for cancer: A lesson from melanoma. Virchows Arch. Int. J. Pathol. 2019, 474, 421-432. [CrossRef]

95. Seidel, J.A.; Otsuka, A.; Kabashima, K. Anti-PD-1 and Anti-CTLA-4 Therapies in Cancer: Mechanisms of Action, Efficacy, and Limitations. Front. Oncol. 2018, 8, 86. [CrossRef]

96. Mosmann, T. Rapid colorimetric assay for cellular growth and survival: Application to proliferation and cytotoxicity assays. J. Immunol. Methods 1983, 65, 55-63. [CrossRef]

97. Labib, M.B.; Philoppes, J.N.; Lamie, P.F.; Ahmed, E.R. Azole-hydrazone derivatives: Design, synthesis, in vitro biological evaluation, dual EGFR/HER2 inhibitory activity, cell cycle analysis and molecular docking study as anticancer agents. Bioorg. Chem. 2018, 76, 67-80. [CrossRef]

98. Shaker, O.G.; Senousy, M.A.; Elbaz, E.M. Association of rs6983267 at 8q24, HULC rs7763881 polymorphisms and serum lncRNAs CCAT2 and HULC with colorectal cancer in Egyptian patients. Sci. Rep. 2017, 7, 16246. [CrossRef]

99. Duan, W.; Du, L.; Jiang, X.; Wang, R.; Yan, S.; Xie, Y.; Yan, K.; Wang, Q.; Wang, L.; Zhang, X.; et al. Identification of a serum circulating lncRNA panel for the diagnosis and recurrence prediction of bladder cancer. Oncotarget 2016, 7, 78850-78858. [CrossRef]

100. Livak, K.J.; Schmittgen, T.D. Analysis of relative gene expression data using real-time quantitative PCR and the $2^{-\Delta \Delta C T}$ Method. Methods 2001, 25, 402-408. [CrossRef]

(C) 2020 by the authors. Licensee MDPI, Basel, Switzerland. This article is an open access article distributed under the terms and conditions of the Creative Commons Attribution (CC BY) license (http://creativecommons.org/licenses/by/4.0/). 